\title{
The Origins of Sulfate in Cenozoic Non-Marine Evaporites in the Basin and-Range Province, Southwestern North America
}

\author{
Ailiang $\mathrm{Gu}^{1}$ and Christopher John Eastoe ${ }^{2, *(D)}$ \\ 1 Jiangsu DDBS Environmental Remediation Co., Ltd., Nanjing 210012, China; guail@jsddbs.com \\ 2 Department of Geosciences, University of Arizona, Tucson, AZ 85721, USA \\ * Correspondence: eastoe@email.arizona.edu
}

Citation: Gu, A.; Eastoe, C.J. The Origins of Sulfate in Cenozoic

Non-Marine Evaporites in the Basin and-Range Province, Southwestern North America. Geosciences 2021, 11, 455. https://doi.org/10.3390/ geosciences11110455

Academic Editors: Salvatore Critelli and Jesus Martinez-Frias

Received: 31 August 2021

Accepted: 28 October 2021

Published: 3 November 2021

Publisher's Note: MDPI stays neutral with regard to jurisdictional claims in published maps and institutional affiliations.

Copyright: (c) 2021 by the authors. Licensee MDPI, Basel, Switzerland. This article is an open access article distributed under the terms and conditions of the Creative Commons Attribution (CC BY) license (https:// creativecommons.org/licenses/by/ $4.0 /)$.

\begin{abstract}
Cenozoic evaporites (gypsum and anhydrite) in southwestern North America have wide ranges of $\delta^{34} \mathrm{~S}\left(-30\right.$ to $+22 \%$; most +4 to $+10 \%$ ) and $\delta^{18} \mathrm{O}_{\mathrm{SO} 4}(+3$ to $+19 \%$ ). New data are presented for five basins in southern Arizona. The evaporites were deposited in playas or perennial saline lakes in closed basins of Oligocene or younger age. Very large accumulations in Picacho, Safford and Tucson Basins have isotope compositions plotting close to a linear $\delta^{34} S-\delta^{18} \mathrm{O}_{\mathrm{SO} 4}$ relationship corresponding to mixing of two sources of sulfur: (1) sulfate recycled from Permian marine gypsum and (2) sulfate from weathering of Laramide-age igneous rocks that include porphyry copper deposits. In the large evaporites, sulfate with $\delta^{34} S>+10 \%$ is dominantly of Permian or Early Cretaceous marine origin, but has locally evolved to higher values as a result of bacterial sulfate reduction (BSR). Sulfate with $\delta^{34} \mathrm{~S}<-10 \%$ formed following exposure of sulfides, possibly formed during supergene enrichment of a porphyry copper deposit by BSR, and have values of $\delta^{18} \mathrm{O}_{\mathrm{SO} 4}$ higher than those of local acid rock drainage because of participation of evaporated water in BSR. Accumulations of 30 to $100 \mathrm{~km}^{3}$ of gypsum in Picacho and Safford Basins are too large to explain as products of contemporaneous erosion of Permian and Laramide source materials, but may represent recycling of Late Cretaceous to Miocene lacustrine sulfate.
\end{abstract}

Keywords: sulfate isotopes; non-marine; evaporites; closed basins; Basin and Range; Arizona; USA

\section{Introduction}

\subsection{Study Context and Scope}

Sulfate minerals, gypsum and anhydrite, commonly occur in terrestrial and marine evaporites as bedded deposits in association with limestone, shale, clay and halite. Environmental factors, including climate, location, topography, and geology, control the supply and enrichment of solutes and determine the type of precipitates formed in closed terrestrial basins. Gypsum formation is commonly limited by the availability of sulfur. Hence, one needs to understand the geochemical cycling of sulfur in order to account for the origins of evaporites [1].

An important aspect of evaporite research centers on their potential use as records of seawater chemistry, tectonic setting, paleoclimate, and palaeohydrology. Sulfur and oxygen isotope compositions in sulfate are useful for identifying sulfate sources and inferring the geochemical environment of sulfate-bearing water $[2,3]$. The $\delta^{34} \mathrm{~S}$ and $\delta^{18} \mathrm{O}_{\mathrm{SO} 4}$ age curves in marine evaporites [4] have been extensively used to date marine evaporites and to determine the marine or non-marine origin of evaporite deposits [5-7]. For instance, $\delta^{34} S$ and $\delta^{18} \mathrm{O}_{\mathrm{SO} 4}$ have been used to determine the origins of sulfur in the evaporites in Paris Basin, France [8], southern Australia [9] and the Namib Desert, Namibia [10].

Non-marine evaporites are largely limited to the Cenozoic; nearly all older evaporites are of marine origin, reflecting the poorer preservation potential of lacustrine sedimentary rocks [11]. Non-marine evaporites generally have lower $\delta^{34} S$ values than marine evaporites because of addition of low- $\delta^{34}$ S sulfur from rainwater, sulfide minerals, volcanic sulfur, 
and terrestrial biogenic sulfur. Non-marine evaporites abound in problems of significance to climate, hydrology, tectonics, sedimentation, geochemistry, and mineralogy [12].

In southwestern North America, evaporites form a prominent part of the Cenozoic stratigraphy of the arid to semiarid Basin-and-Range Province [13]. Syn-extensional Cenozoic evaporites are common in Southern California (Death Valley, Saline Valley, Searles Lake, and Bristol Dry Lake), Nevada (Virgin basin), Arizona (Hualapai, Detrital, Luke, Picacho, Chandler, Tucson, Safford, San Pedro, and Douglas basins), New Mexico (Tularosa basin), Texas (Hueco Bolson), and northern Sonora (Magdalena and Tubutama basins) [14-17]. In many cases, surface exposure is limited. Gypsiferous soils are also common in this region $[18,19]$. The distribution and origin (marine vs. non-marine) of the evaporites has significant implications for the Cenozoic paleogeography of the western Cordillera [16].

Arizona has the thickest documented Cenozoic evaporites in the Basin-and-Range Province. They consist mainly of halite, gypsum and anhydrite, and occur from southeastern to northwestern Arizona, largely coinciding with a province of porphyry copper deposits (PCDs) (Figure 1). This group of evaporites includes $1800 \mathrm{~m}$ of anhydrite in the Picacho basin [14], >800 $\mathrm{m}$ of gypsum and anhydrite in Chandler basin [20], >320 $\mathrm{m}$ of gypsum and anhydrite in Tucson basin [20,21], $>690 \mathrm{~m}$ of gypsum, anhydrite and halite in Safford basin [22], >1200 $\mathrm{m}$ of halite in the Luke basin [23], and $>1280 \mathrm{~m}$ of halite in the Hualapai basin [14]. Some have economic value, and others are considered ideal locations to store nuclear waste and natural gas [24].

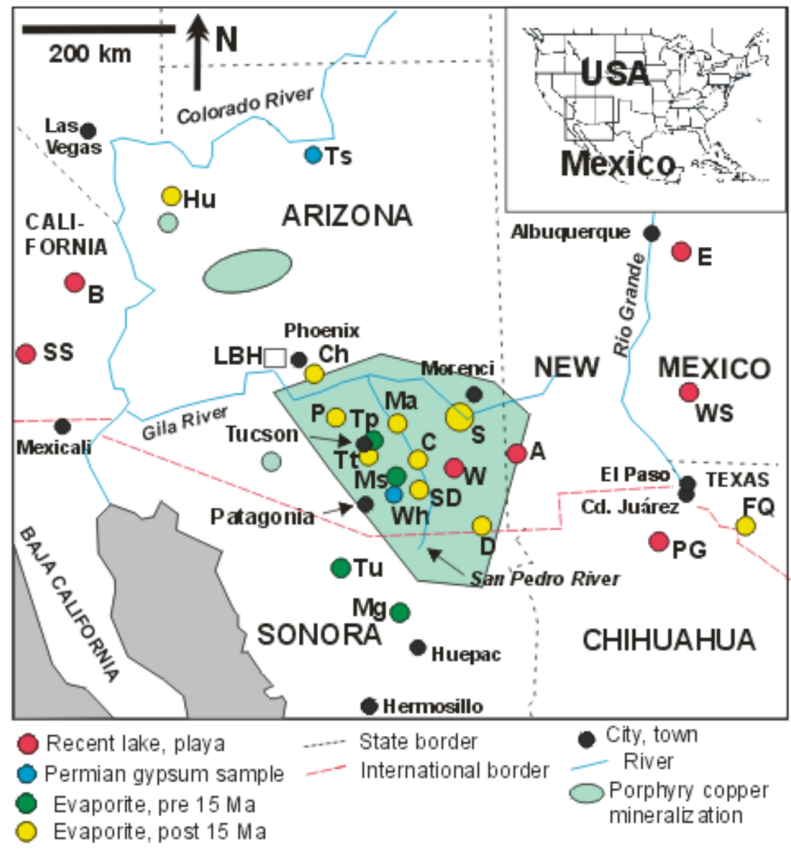

Figure 1. Map of southwest North America, showing locations mentioned in the paper relative to zones of porphyry copper mineralization. A = Animas Playa; B = Bristol Lake; C = Cascabel; $\mathrm{Ch}=$ Chandler Basin; D = Douglas; E = Estancia Basin; FQ = Fort Quitman; Hu = Hualapai Basin; $\mathrm{LBH}=$ Luke Basin halite; Ma = Mammoth; Mg = Magdalena; Ms = Marsh Station; P = Picacho Basin; PG = Playa Guzman; S = Safford Basin; SD = Saint David; SS = Salton Sea; Tp = Tucson Basin, Pantano Formation; $\mathrm{Tt}$ = Tucson Basin, Tinaja Beds; $\mathrm{W}=$ Willcox Playa; $\mathrm{WS}=$ White Sands dune field; Wh $=$ Whetstone Mountains. Details of sample locations in the Safford and Tucson Basins and at Douglas are given in Supplementary Figures S1-S3.

This article is an evaluation of the sulfur sources responsible for the gypsum and anhydrite accumulations in southwestern North America, using sulfur and oxygen stable isotope data. New data, mainly from basins in Arizona, are combined with published data. Isotopes may be used as source tracers if the isotope compositions of the sources are known and are distinctive, and if the isotopic changes that occur during physical, chemical, and 
biological transformations are understood. The main objectives are: (1) to characterize $\delta^{34} S$ and $\delta^{18} \mathrm{O}_{\mathrm{SO} 4}$ of sulfate in the evaporites in the study area, (2) to constrain the origins and evolution of the sulfur, (3) to account for sources of sulfur, and (4) evaluate mechanisms leading to the distribution of the evaporites in space and time.

\subsection{Study Area}

In southwestern North America (Figure 1), the Basin-and-Range Province comprises multiple mountain ranges separated by fault-bounded basins with relatively little relief. The basins contain deposits of alluvium derived from the ranges, along with lesser volumes of evaporite and volcanic rock [25]. The Province formed at a time of Neogene tectonic extension [26]. A hard-rock plateau was fractured in an initial phase of low-angle normal faulting, followed by high-angle normal faulting that produced depressions. The depressions accumulated basin fill to typical thicknesses of $1500 \mathrm{~m}$, and locally more than $3400 \mathrm{~m}$ [25]. In Arizona, Basin-and-Range development began $12 \mathrm{Ma}$ ago in the northwest and $15 \mathrm{Ma}$ ago in the southeast [26]. Surface drainage became integrated except in a closed section of Willcox basin following deepening of the Lower Colorado River watercourse [27]. In the Miocene and Pliocene, when internal drainage was common, hundreds of meters of lacustrine deposits, including evaporites, accumulated in several basins [20,27].

The hard-rock ranges bordering the basins considered here consist of complex juxtapositions of sedimentary and volcanic strata of Paleoproterozoic to Neogene age, and their metamorphic equivalents. Granitic intrusions are prominent. Permian marine gypsum and Cretaceous-Paleogene igneous rocks with PCDs are common in the bordering ranges.

Approximate age relationships are shown in Figure 2. In most of the study areas, it is not possible to recognize gypsum depositional facies, because samples consist of 1-3 mm drill-core cuttings, and because recrystallization is widespread.

\begin{tabular}{|c|c|c|c|c|c|c|}
\hline AGE & PICACHO & TUCSON & SAN PEDRO & \multicolumn{2}{|c|}{ SAFFORD } & OTHER \\
\hline Holocene & & & $\begin{array}{l}\text { Unnamed lacustrine } \\
\text { clay }\end{array}$ & & & Douglas \\
\hline \multicolumn{7}{|l|}{ Pleistocene } \\
\hline Pliocene & & & $\begin{array}{l}\text { St. David Fm. }<3.6 \mathrm{Ma} \\
\text { Quiburis Fm. }\end{array}$ & $\begin{array}{l}\text { Sanchez } \\
\text { Beds }\end{array}$ & $\begin{array}{l}\text { Bear Springs } \\
\text { Wash Beds }\end{array}$ & \\
\hline Miocene & $14.9-10.5 \mathrm{Ma}$ & Tinaja Beds & $11-5 \mathrm{Ma}$ & & & $\begin{array}{l}\text { Hualapai, 13-9 Ma, ?Luke } \\
\text { Magdalena, Tubutama } 22 \mathrm{Ma}\end{array}$ \\
\hline Oligocene & & $\begin{array}{l}\text { Pantano Fm. } \\
27-26 \mathrm{Ma}\end{array}$ & $\begin{array}{l}\text { Mineta Fm. } \\
34-26 \mathrm{Ma}\end{array}$ & & & \\
\hline \multicolumn{4}{|l|}{ REGIONAL } & \multicolumn{3}{|c|}{ Fm. = Formation } \\
\hline Late Cretaceous & \multicolumn{3}{|c|}{ Cabullona Group, Sonora } & & \multicolumn{2}{|c|}{ Major Ca sulfate } \\
\hline Early Cretaceous & \multicolumn{3}{|c|}{ Bisbee Group, Southern Arizona and Sonora } & & \multicolumn{2}{|c|}{ Minor Ca sulfate } \\
\hline Late Permian & Epitaph Fm., & Southern Ariz & & & & \\
\hline
\end{tabular}

Figure 2. Approximate age relationships of Basin and Range Province evaporites.

\subsubsection{Picacho Basin}

Picacho Basin is one of several basins in central Arizona known collectively as the Gila Low, a region of internal drainage early in the formation of the Basin-and-Range Province [28]. Picacho Basin accumulated over $3000 \mathrm{~m}$ of Neogene continental sediments [29]. Fine sand, silt, clay, and evaporites were deposited in playas or ephemeral lakes [30]. The Exxon State (74)-1 well penetrated about $1800 \mathrm{~m}$ of massive anhydrite containing minor interbeds of shale, tuff, halite, and limestone nodules. The evaporites are of middle to late Miocene age, 14.9 to $10.5 \mathrm{Ma}$ [20].

\subsubsection{Tucson Basin}

Basin fill consisting of conglomerate, sandstone and gypsiferous mudstone of Oligocene to Holocene age, is up to 3000 meters thick in the central graben of the basin [21]. Gypsum or anhydrite evaporites occur in the Oligocene (Pantano Formation) to Miocene (Tinaja Beds) strata, both at depth and at the basin margins. In the Exxon State (32)-1 well the interval 546 to $686 \mathrm{~m}$ contained an abundance of gypsum and anhydrite crystals [20,21]. In 
the Pantano Formation, small nodules of gypsum were sampled from outcrop at Marsh Station at the southeastern margin of the basin, and massive gypsum from a disused gypsum quarry at the northern margin. Gypsum samples from the Tinaja beds were obtained from cuttings from three drill holes near the center of the basin.

\subsubsection{San Pedro Basin}

Commercial gypsum deposits are quarried at Mammoth in the Miocene-Pliocene Quiburis Formation, which accumulated in the closed San Pedro Trough between 11 and $5 \mathrm{Ma}$ ago [31]. The northern part of the Formation, the Redington Member, consists of clayrich sediments with local massive gypsum beds. Three additional sites of different age were sampled. In the upper San Pedro Basin, the alluvial-lacustrine St. David Formation [32] contains minor gypsum of probable Pliocene or Pleistocene age in outcrop about $8 \mathrm{~km}$ southwest of St. David. At Cascabel, a small lacustrine clay deposit of probable Holocene age next to the San Pedro River contains abundant, dispersed crystals of a sodium sulfate mineral. On the east flanks of the San Pedro valley at Cascabel, the Mineta Formation, a volcaniclastic redbed conglomerate of probable Oligocene age [33] contains a lens of recrystallized gypsum up to $1 \mathrm{~m}$ thick in a lacustrine member.

\subsubsection{Safford Basin}

Seismic reflection profiling [34,35] revealed the basin to be a half-graben, with the southwest side downfaulted along a secondary breakaway fault. Basin-fill consists of conglomerate, silt, clay and evaporites with minor lacustrine limestone and diatomite [36,37]. In the basin center, the Sanchez Beds consist of $250 \mathrm{~m}$ of clay, gypsum/anhydrite, and halite, and are overlain by $520 \mathrm{~m}$ of Pliocene lacustrine units. Fine-grained Pliocene lacustrine sediments and alluvial fan deposits, the Bear Springs Wash Beds (BSWB), interfinger with the Sanchez beds and older basin fill in the southwest part of the basin.

A 1971 drill hole (Tenney \#3 State well) about $32 \mathrm{~km}$ south of Safford, encountered $700 \mathrm{~m}$ of gypsum and anhydrite below $366 \mathrm{~m}$ and terminated in evaporites at $1068 \mathrm{~m}$. The full thickness is unknown [22]. Gypsum/anhydrite of the Sanchez Beds was taken from three sets of well cuttings, from the Tenney \#3 State, Claridge and City of Safford wells. In addition, gypsum was collected from the BSWB in Frye, Hall and Riggs Mesas along the southwestern basin margin, where outcrop includes red and green shales with scattered thin beds of gypsum, pyritic shale and white tuff. They remain exposed along the mountain front in an area where breakaway faulting has migrated toward the basin center. Sulfate was also extracted from lacustrine clay and ocher outcrops along the Gila River between Safford and Geronimo.

\subsubsection{Unnamed Basin, Douglas}

The basin is located about $8 \mathrm{~km}$ east of Douglas, Arizona. Two disused quarries expose irregular, near-surface lenses of light buff to white gypsum and gypsite up to $2 \mathrm{~m}$ thick. The lenses overlie Cenozoic, possibly Pleistocene, clay. Coarse yellow crystals of gypsum occur locally at the base of the soil. An active sulfate source is apparent: in D Hill, $1 \mathrm{~km}$ south of the quarries, altered Paleozoic limestone contains goethite casts of coarse pyrite crystals, some with sulfide cores. Small gullies drain the north slope of D Hill and lead to the quarries. The gypsum appears to have formed where sulfate-bearing water from D Hill has evaporated on infiltrating basin-fill sediment in a small basin that is open to the north. Gypsum, pyrite from the limestone and sulfate from dry stream sediment (representing integrated sulfate supplied in runoff) were sampled.

\subsubsection{Modern Playas}

Animas Playa, New Mexico, Willcox Playa, Arizona and Playa Guzmán, Chihuahua are ephemeral lakes within internal drainage basins. The Salton Sea, California, has been a permanent lake since the early 20th Century. 


\subsection{Environment of Evaporite Formation}

The terrestrial Cenozoic setting of the province indicates that most of the evaporites accumulated in isolated interior-drainage basins, mostly likely in environmental settings like modern playas and saline lakes $[14,16]$. Lacustrine conditions ended in most areas between 10.5 and $5 \mathrm{Ma}[20,31]$.

Evaporitic basins are hydrologically closed; that is, evaporation exceeds inflow under an arid to semi-arid climate regime. Evaporite deposits can form only where sufficient supply of solutes is available in inflow. These seemingly conflicting requirements are reconciled in orographic deserts, where high mountains catch precipitation and generate rain shadows on neighboring basin floors [12]. In this regard, the Basin-and-Range Province has provided ideal conditions in the past for the formation of lacustrine evaporites. The thicker known evaporites occur near the northeastern margin of the Province, proximal to the Transition Zone bordering the Colorado Plateau.

Deposition of great thicknesses of evaporites in short time intervals is well documented. High evaporation in arid regions permits accumulation of sulfates at rates of $1-40 \mathrm{~m} / 1000$ years and halite at $10-100 \mathrm{~m} / 1000$ years [38,39]. At such rates, the thick anhydrite evaporites in Picacho basin could form in 45,000 to 1.8 million years.

\subsection{Origins of Sulfur in Non-Marine Evaporites}

Sulfur cycling and the behavior of sulfate isotopes in surface environments have been reviewed in [40] and references therein. In non-marine basins, numerous sources of sulfur and numerous pathways of sulfur supply are possible. Rainwater, dust, surface water, and groundwater can all transport the sulfate from source areas to the lacustrine environments where sulfate evaporites form. Possible sulfate sources are: (1) marine aerosols (cyclic salts) and dimethysulfide (DMS); (2) dissolution of pre-existing evaporites within the drainage basin; (3) sulfate in connate water or dispersed in non-evaporitic marine sediments; (4) weathering of sulfide-bearing rock; (5) biogenic reduced sulfur; and (6) anthropogenic sulfur, including soil amendments, fertilizers and combustion products. Compiled ranges of $\delta^{34} S$ from studies of non-marine evaporites published prior to 1994 have been compared with the ranges for marine sulfate and DMS [40]; the authors noted that single or mixed multiple sources of sulfur may apply in a single basin.

Sulfate generated by oxidation of sulfide commonly has $\delta^{34} S$ values close to those the sulfide and low values of $\delta^{18} \mathrm{O}_{\mathrm{SO} 4}$ [40]. Values of $\delta^{18} \mathrm{O}_{\mathrm{SO} 4}$ result from the incorporation into sulfate of $\mathrm{O}$ from water in addition to atmospheric $\mathrm{O}_{2}$, e.g., according to the following reactions for oxidation of pyrite [41]:

$$
\begin{gathered}
\mathrm{FeS}_{2}+7 / 2 \mathrm{O}_{2(\mathrm{aq})}+\mathrm{H}_{2} \mathrm{O} \rightarrow \mathrm{Fe}^{2+}+2 \mathrm{SO}_{4}{ }^{2-}+2 \mathrm{H}^{+} \\
\mathrm{FeS}_{2}+14 \mathrm{Fe}^{3+}+8 \mathrm{H}_{2} \mathrm{O} \rightarrow 15 \mathrm{Fe}^{2+}+2 \mathrm{SO}_{4}{ }^{2-}+16 \mathrm{H}^{+}
\end{gathered}
$$

The second reaction is rate-limited under acid conditions by the reaction

$$
\mathrm{Fe}^{2+}+1 / 4 \mathrm{O}_{2(\mathrm{aq})}+\mathrm{H}^{+} \rightarrow \mathrm{Fe}^{3+}+1 / 2 \mathrm{H}_{2} \mathrm{O}
$$

which is greatly accelerated by Thiobacillus ferrooxidans in submersed and anaerobic environments [42,43]. Atmospheric $\mathrm{O}_{2}$, with $\delta^{18} \mathrm{O}+23.5 \%$ [44] differs greatly in $\delta^{18} \mathrm{O}$ from meteoric water; therefore Equations (1) and (2) should yield sulfate with distinctive ranges of $\delta^{18} \mathrm{O}_{\mathrm{SO}}$. Both reactions may occur concurrently, but in acid mine drainage in the western USA, Equation (2) typically dominates [43]. In Miocene gypsum from southern Poland, Equation (1) appears to dominate; sulfate derived by oxidation of coal-bed reduced sulfur has $\delta^{18} \mathrm{O}_{\mathrm{SO} 4}$ values of +18 to $+20 \%$, approaching that of atmospheric $\mathrm{O}_{2}$ [45]. 


\subsection{Evolution of $\delta^{34} S$ and $\delta^{18} O$ in Sulfate Evaporites}

Under lacustrine conditions, no oxygen isotope exchange occurs between sulfate ions and water [46]. Aqueous sulfate in lake water preserves the $\delta^{34} \mathrm{~S}$ and $\delta^{18} \mathrm{O}_{\mathrm{SO} 4}$ of its sources unless the sulfate is subjected to one of the following processes.

Isotope fractionation occurs between gypsum and coexisting aqueous sulfate. Under evaporitic conditions, $\Delta^{34} \mathrm{~S}$ and $\Delta^{18} \mathrm{O}_{\mathrm{SO} 4}$ (gypsum-aqueous sulfate) are about $+1.65 \%$ and $+3.5 \%$, respectively [47-49]. In a small sulfate reservoir, early-deposited gypsum has higher values of $\delta^{34} \mathrm{~S}$ and $\delta^{18} \mathrm{O}_{\mathrm{SO} 4}$ than later-crystallized gypsum. If cyclic dissolution and recrystallization of gypsum are accompanied by removal of some aqueous sulfate, fractionation may accumulate in the residual solid. Such cumulative fractionation may occur in vadose playas, as suggested for $\mathrm{Cl}$ isotopes [50]. Gypsum dehydration and diagenetic redistribution of sulfate do not generate significant isotope fractionation [51].

Bacterial sulfate reduction (BSR) and thermochemical sulfate reduction (TSR) produce sulfide species from dissolved sulfate by reaction with organic matter [52]. BSR occurs in near-surface environments and water columns at temperatures up to $80^{\circ} \mathrm{C}$ [53] or possibly higher [52]. TSR, which occurs at temperatures above $100{ }^{\circ} \mathrm{C}$ [53] is improbable in the depositional environment of evaporites or in weathering profiles, but is possible where buried gypsum recrystallizes as anhydrite at temperatures above $90.5^{\circ} \mathrm{C}$ [54].

Partial BSR causes increases in both $\delta^{34} \mathrm{~S}$ and $\delta^{18} \mathrm{O}_{\mathrm{SO}}$ in residual sulfate in experiments utilizing single bacterial species and single organic-compound substrates, provided that ambient water is not greatly depleted in ${ }^{18} \mathrm{O}$. Change in $\delta^{18} \mathrm{O}_{\mathrm{SO} 4}$ appears to arise from isotope exchange between water and $\mathrm{S}^{4+}$ reaction intermediaries, and produces scattered results, even in simple experimental situations; it does not show a simple relationship with change in $\delta^{34} S[55,56]$. Natural BSR by multiple microbial species exploiting complex organic substrates is less likely to produce predictable relationships between $\delta^{34} \mathrm{~S}$ and $\delta^{18} \mathrm{O}_{\mathrm{SO} 4}$ in residual sulfate. While BSR can readily fractionate sulfate isotopes in aqueous sulfate, it is unlikely to shift $\delta^{34} \mathrm{~S}$ of pre-existing massive gypsum or anhydrite. Minute pyrite crystals surrounding gypsum crystals buried beneath Bristol Dry Lake, California [57] represent BSR of sulfate dissolved from the gypsum, but the BSR is unlikely to have affected the $\delta^{34} S$ of the remaining gypsum.

\subsection{Previous Geochemical and Isotope Studies of Nonmarine Evaporites in Southwest North America}

Low Br content (2-6 ppm) suggested a nonmarine origin for Miocene halite in Luke Basin, Arizona [23]. Modern perennial saline lakes in the western USA have a $\delta^{18} \mathrm{O}_{\mathrm{SO}}$ range of +13.3 to $+23.2 \%$ [58]. In the Bristol Dry Lake basin, California, the range of $\delta^{34} \mathrm{~S}$ values of near-surface $(<2 \mathrm{~m})$ gypsum, anhydrite, and celestite was +6 to $+9 \%$, while 12 core samples (286 to $517 \mathrm{~m}$ ) had lower $\delta^{34} \mathrm{~S}$ values in the range 0 to $+4 \%$ [57]. In the Hualapai basin halite body, Arizona, $\delta^{34} \mathrm{~S}$ and $\delta^{18} \mathrm{O}_{\mathrm{SO} 4}$ values were $+6.8 \%$ and $+5.9 \%$, respectively, in an intercalated anhydrite layer, and $+11.3 \%$ and $+11.5 \%$ in the anhydrite cap [16]. The $\delta^{34} \mathrm{~S}$ value of the intercalated anhydrite is significantly lower than those of Phanerozoic marine sulfate [4], indicating a non-marine origin. A 200,000-year record of gypsum, glauberite and mirabilite in Death Valley, California shows $\delta^{34} S$ values from +5 to $+22 \%$, and $\delta^{18} \mathrm{O}_{\mathrm{SO} 4}$ from +9 to $+23 \%$ [59]. The $\delta^{18} \mathrm{O}_{\mathrm{SO} 4}$ values probably reflect changes in lake level, reduction of sulfate and re-oxidation of sulfide and/or differences in crystallization temperature of the sulfate minerals. Ephemeral lake conditions (warm, shallow water) resulted in precipitation of sulfate with lower $\delta^{18} \mathrm{O}_{\mathrm{SO} 4}$ values. Wet, cold, stratified, and perennial lake conditions resulted in precipitation of sulfate with high $\delta^{18} \mathrm{O}_{\mathrm{SO} 4}$ values because of re-oxidation of sulfide formed by BSR in the lower water or bottom mud. At the White Sands and Estancia gypsum dune fields, New Mexico, $\delta^{34} \mathrm{~S}$ values imply recycling of Permian marine gypsum, with superimposed BSR at Estancia [60]. 


\subsection{Sulfate Isotopes in Precipitation}

Anthropogenic emissions have accounted for $75-84 \%$ of sulfur in the atmosphere of the Northern Hemisphere since 1980 [61,62]. In the southwest USA, major sources have been copper smelters and coal-fired electric power stations. Rainwater sulfate collected in Tucson Basin between 1996 and $2003[63,64]$ had a $\delta^{34} S$ range of +2.1 to $+8.0 \%$ with a mean, weighted for precipitation amount, of $+4.0 \%$. A small dataset for $\delta^{18} \mathrm{O}_{\mathrm{SO} 4}$ ranged from +8.4 to $+12.0 \%$, with an average of $+10.2 \%$. Sulfate in pre-industrial precipitation, lacking anthropogenic input, contained mostly sulfur of volcanic and marine biogenic sources [61], except in desert regions where wind-blown dust may contribute sulfate. In the study area, detectable marine sulfate aerosol appears to penetrate only to windward slopes of mountain ranges bordering the Gulf of California, on the evidence of $\mathrm{SO}_{4} / \mathrm{Cl}$ ratios in groundwater [65]. Desert varnish sampled as a proxy for pre-industrial atmospheric sulfate had average values of $+7.9 \pm 0.9 \%$ for $\delta^{34} \mathrm{~S}$ and $+6.4 \pm 1.1 \%$ for $\delta^{18} \mathrm{O}_{\mathrm{SO} 4}$ in sulfate [66]; the authors determined means of $+5.8 \pm 1.4 \%$ o $\left(\delta^{34} \mathrm{~S}\right)$ and $+11.2 \pm 1.1 \%$ o $\left(\delta^{18} \mathrm{O}_{\mathrm{SO} 4}\right)$ for modern atmospheric sulfate. In Tucson Basin, young groundwater (containing detectable tritium) had lower values of $\delta^{34} S$ than pre-bomb groundwater [67], indicating a sense of change like that of the desert varnish data.

\subsection{Bedrock Sulfate and Sulfide}

Available $\delta^{34} \mathrm{~S}$ and $\delta^{18} \mathrm{O}_{\mathrm{SO} 4}$ data for bedrock, including PCDs, in the study area are summarized in Table 1. Sulfate collected from springs or wells drilled in bedrock is assumed to represent the sulfur disseminated in the bedrock. Both $\delta^{34} \mathrm{~S}$ and $\delta^{18} \mathrm{O}_{\mathrm{SO} 4}$ in the bedrock have wide ranges, from -6 to $+25 \%$ and -2 to $+13 \%$, respectively. Bedrock types important in this study area are:

(a) Late Paleogene felsic volcanic rocks and associated granitoids, low in sulfur content. No $S$ isotope data are available.

(b) Mylonitic granitic gneiss of the Santa Catalina and Rincon Mountains. Lowsulfur rocks have $\delta^{34} \mathrm{~S}$ from +2 to $+12 \%$, and $\delta^{18} \mathrm{O}_{\mathrm{SO} 4},+3$ to $+11 \%$ o $[63,68]$. In highsulfate groundwater (156-344 ppm) associated with the western range-front of the Rincon Mountains, the $\delta^{34} \mathrm{~S}$ range is +7 to $+9 \%$, and the $\delta^{18} \mathrm{OSO}_{\mathrm{SO}}$ range, -1 to $+2 \%$, indicates oxidation of sulfide [63].

(c) Laramide (Late Cretaceous-Paleocene) intermediate volcanic rocks and associated granitoids with numerous large PCDs. PCDs and overlying cap rock have high concentrations of sulfur. Wells drilled in these strata generally produce groundwater with high sulfate concentration. In the Patagonia Mountains, wells, springs and acid rock drainage generally have high concentrations of sulfate $(60-3000 \mathrm{ppm}) ; \delta^{34} \mathrm{~S}$ ranges from -10.7 to $+0.1 \%$, and $\delta^{18} \mathrm{O}_{\mathrm{SO} 4}$ from -2.2 to $+3.4 \%$ o $[63,69,70]$. In the Tucson Mountains, $\delta^{34} \mathrm{~S}$ in groundwater hosted by Laramide igneous rock ranges from +1 to $+3 \%$, and $\delta^{18} \mathrm{O}_{\mathrm{SO} 4}$ from +2 to $+7 \%$ [66]. Low $\delta^{18} \mathrm{O}_{\mathrm{SO} 4}$ values in both cases result from oxidation of sulfide.

The PCDs contain abundant sulfide minerals, and sulfate minerals of both hypogene (anhydrite) and supergene (gypsum, alunite, jarosite, and $\mathrm{Cu}-\mathrm{Fe}$ sulfates) origins. Supergene sulfide and sulfate form by oxidation-reduction reactions during weathering of hypogene sulfide. Available isotope data for hypogene minerals are summarized in Figure 3. Values of $\delta^{34} \mathrm{~S}$ in hypogene sulfide range from -2 to $+3 \%$, consistent with the global range for PCDs [71]. Hypogene sulfate has a wide range of values of $\delta^{34} \mathrm{~S}(+6$ to $+17 \%$ ) and $\delta^{18} \mathrm{O}_{\mathrm{SO} 4}\left(+7\right.$ to $+20 \%$ ); data fall close to the $\delta^{34} \mathrm{~S}=\delta^{18} \mathrm{O}_{\mathrm{SO} 4}$ line in several instances. Supergene sulfide at the Morenci PCD has $\delta^{34} S$ values as low as $-31 \%$, reflecting BSR during supergene enrichment [72].

The mass ratio of hypogene sulfate to hypogene sulfide may be about 1:2 in the PCDs of southern Arizona (E. Seedorff, personal communication). Assuming mean $\delta^{34} \mathrm{~S}$ values of $0 \%$ in sulfide and $+10 \%$ in hypogene sulfate (averages of available data), then the $\delta^{34} \mathrm{~S}$ of bulk sulfate weathered from PCDs would be $+3.3 \%$. The Mineral Park deposit has more positive mean hypogene $\delta^{34} \mathrm{~S}$ values than other PCDs in the region, $+2.4 \%$ for sulfide and $+14.7 \%$ for sulfate [73]; in this case the bulk $\delta^{34} \mathrm{~S}$ would be $+6.5 \%$. It is difficult 
to estimate the total sulfur content of an entire PCD system, including ore, capping rock and lateral disseminations. Giant PCD orebodies may contain up to $10^{9} \mathrm{t}$ of sulfide-S, and $1.5 \times 10^{9} \mathrm{t}$ total S [74,75]; for comparison, the Morenci deposit in Arizona may have contained $0.24 \times 10^{9}$ t S in supergene-enriched ore [72]. Supergene enrichment (and therefore erosion) of PCDs in southern Arizona began in the Mid-Miocene at $13 \mathrm{Ma}$ and was most intense from 11 to $7 \mathrm{Ma}$ [72,76] contemporaneous with the formation of deep evaporite basins and deposition of massive evaporites.

(d) Mesozoic sedimentary rocks. These generally have low sulfur contents; e.g., 30 to $285 \mathrm{ppm}$ in Cretaceous sedimentary rocks in southern Arizona [77]. The last marine incursion in southern Arizona resulted in the deposition of the Bisbee Group of Early Cretaceous age [78]. Corresponding marine sulfate $\left(\delta^{34} \mathrm{~S}+15 \pm 2 \%, \delta^{18} \mathrm{O}_{\mathrm{SO} 4}+13.5 \pm\right.$ $1.5 \%$ ) [4] may have survived as traces of evaporitic gypsum in a coastal lagoonal facies [79] or in connate water. In a lacustrine unit of the terrestrial Late Cretaceous Cabullona Group [80] near Huépac, northern Sonora, Mexico, $\delta^{34} \mathrm{~S}$ ranges from +10 to $+16 \%$, and $\delta^{18} \mathrm{O}_{\mathrm{SO} 4}$ from +6 to $+15 \%$ [81].

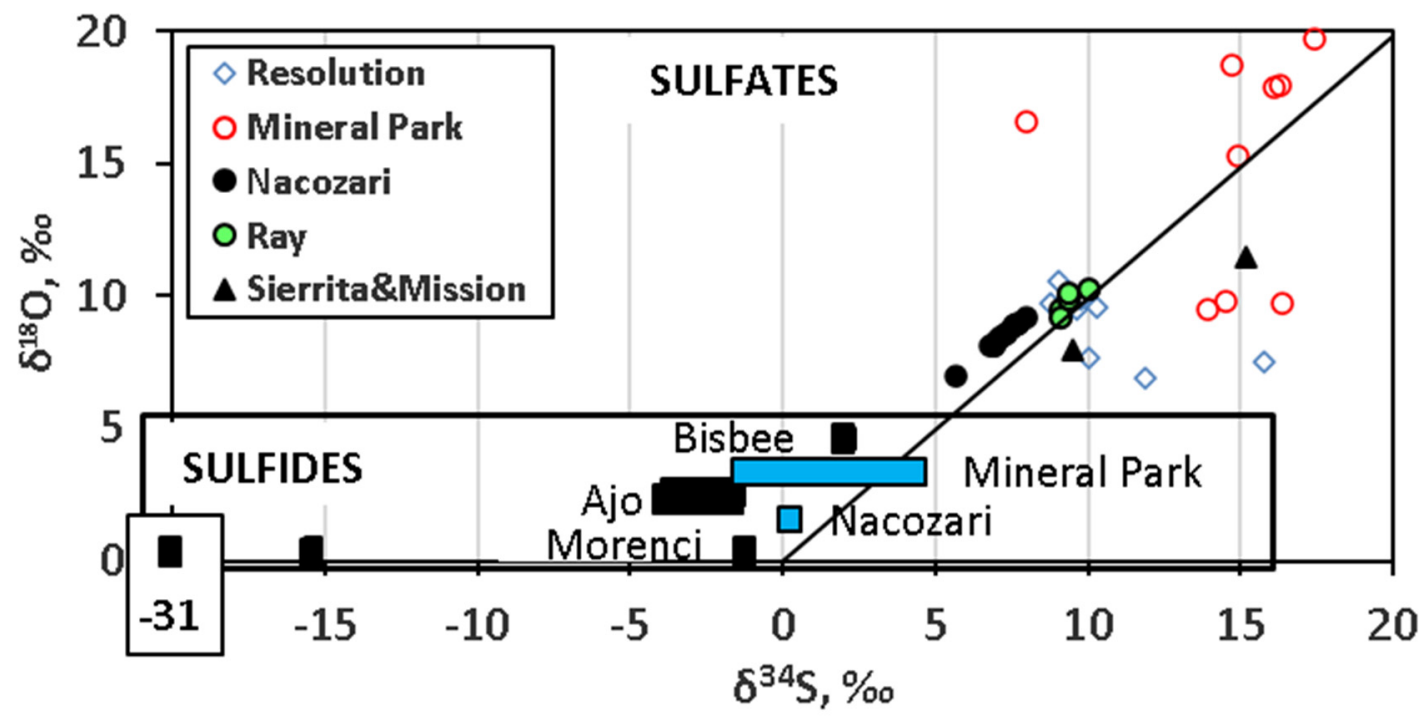

Figure 3. Values and ranges of $\delta^{34} \mathrm{~S}$ and $\delta^{18} \mathrm{O}$ for sulfate and sulfide minerals in porphyry copper deposits of the study area. Values for anhydrite are presented as a plot of $\delta^{18} \mathrm{O}$ vs. $\delta^{34} \mathrm{~S}$. Ranges for sulfide minerals are shown in the inset. Data sources: Mineral Park [73], Morenci [72], Ajo and Bisbee [76], Nacozari [81], others, this study.

(e) Paleozoic marine strata. The Permian Epitaph Formation, containing the oldest known evaporitic gypsum-anhydrite in southern Arizona, formed in a restricted basin transitional between marine and continental environments [82]. A gypsum sample from the Whetstone Mountains gave $\delta^{34} \mathrm{~S}$ and $\delta^{18} \mathrm{O}_{\mathrm{SO} 4}$ values of $+11.7 \%$ and $+12.8 \%$, respectively. Gypsum from the Permian Kaibab Formation in northern Arizona yielded a $\delta^{34} S$ value of $+13 \%$ [73]. These data are typical of Permian marine evaporites [4]. Pyrite from Paleozoic sulfidic limestone on D Hill near Douglas has a $\delta^{34} S$ range of +3 to $+21 \%$. This limestone is heavily altered; therefore, the pyrite may be secondary.

(f) Proterozoic Apache group - Pioneer Shale. The average sulfur content of three shale samples was 2710 ppm [77]. In the present study, two pyrite samples from Tucson area gave $\delta^{34} S$ values of +25.7 and $+25.9 \%$. Jarosite coating weathered outcrop has $\delta^{34} S$ values of +18 to $+25 \%$, and $\delta^{18} \mathrm{O}_{\mathrm{SO}} 4$ values of $-1 \%$ o to $+1 \%$.

(g) Lower Proterozoic strata and intrusions. A sample of groundwater from Paleoproterozoic granite at Payson, Arizona gave a $\delta^{34} S$ value of $+0.6 \%$, which may represent igneous sulfur; higher $\delta^{34} S$ values in other groundwater samples from granite near Payson appear to reflect dissolved Permian gypsum [83]. In central Arizona, lower Proterozoic volcanogenic massive sulfide deposits have a $\delta^{34} S$ range of $0 \pm 3 \%$, probably representing contemporaneous igneous sulfide from the host felsic volcanic suite [84]. 
Table 1. Isotope composition of bedrock sulfur in the study area.

\begin{tabular}{|c|c|c|c|c|c|}
\hline \multirow{2}{*}{ Rock-Type } & \multirow{2}{*}{ Location } & \multirow{2}{*}{ Material } & $\delta^{34} S$ & $\delta^{18} \mathrm{O}$ & \multirow{2}{*}{ Source } \\
\hline & & & $\%$ & $\%$ & \\
\hline Laramide igneous & Tucson Mts. & GW & +1 to +3 & & [63] \\
\hline Laramide igneous & Patagonia Mts. & ARD & -10.7 to +0.1 & -2 to +2 & {$[63,69,70]$} \\
\hline Jurassic igneous & Sta. Rita Mts., Tucson basin & GW & +1 to +3 & & [84] \\
\hline Permian marine evaporite & Whetstone Mts. & gypsum & +11.7 & +12.8 & [63] \\
\hline Permian marine evaporite & Tusayan, Colorado Plateau & gypsum & +13 & & [73] \\
\hline Proterozoic/Eocene granitic gneiss & Rincon Mts., Tucson Basin & GW, high-SO ${ }_{4}^{*}$ & +8.5 to +10.3 & -0.8 to +2.0 & [63] \\
\hline Proterozoic/Eocene granitic gneiss & Rincon Mts., Tucson Basin & $\mathrm{GW}$, low- $-\mathrm{SO}_{4} \#$ & +2.4 to +12.1 & +3.5 to +10.3 & $\mathrm{E}$ \\
\hline Proterozoic/Eocene granitic gneiss & Sta.Catalina Mts., Tucson Basin & GW & +3 to +9 & +4 to +11 & [68] \\
\hline Proterozoic Pioneer shale & Sta.Catalina Mts., Tucson Basin & pyrite & $+25.5,+25.7$ & & this study \\
\hline Proterozoic Pioneer shale & Sta.Catalina Mts., Tucson Basin & jarosite & 17.8 & -0.1 & this study \\
\hline Proterozoic Pioneer shale & Sta.Catalina Mts., Tucson Basin & jarosite & 25.1 & 1.0 & this study \\
\hline Proterozoic Pioneer shale & Sta.Catalina Mts., Tucson Basin & jarosite & 18.3 & -1.1 & this study \\
\hline Proterozoic felsic volcanic rock & Central Arizona & VMS & $0 \pm 3$ & & [85] \\
\hline
\end{tabular}

GW = Ground Water Sta. = Santa * GW confined beneath detachment fault E = Eastoe, unpublished data \# GE in springs VMS = volcanogenic massive sulfide.

\section{Materials and Methods}

Sulfate minerals and sulfate-rich sediment samples were collected from outcrop, well cuttings and drill core. Single water samples were collected from the modern playas, except for Willcox Playa, where gypsiferous dune sand was collected. Sample locations are shown in Figure 1. Detailed sample locations for Tucson and Safford Basins and the site near Douglas are given as supplementary Figures S1-S3. Approximately $300 \mathrm{mg}$ of gypsum/anhydrite was dissolved in warm $1 \mathrm{~N} \mathrm{HCl}$. Water samples were acidified with $1 \mathrm{~N}$ $\mathrm{HCl}$ to remove carbonate species. The warm solutions were filtered to remove any solid residues, and sufficient $10 \% \mathrm{BaCl}_{2}$ solution was added to precipitate all sulfate as $\mathrm{BaSO}_{4}$; solutions were allowed to stand for an hour to complete the precipitation. The $\mathrm{BaSO}_{4}$ was filtered, washed thoroughly with deionized water and dried. Both $\delta^{34} \mathrm{~S}$ and $\delta^{18} \mathrm{O}$ were analyzed in the Environmental Isotope Laboratory, University of Arizona. For S isotopes, $15 \mathrm{mg}$ of $\mathrm{BaSO}_{4}$ was mixed with $60 \mathrm{mg}$ each of $\mathrm{Cu}_{2} \mathrm{O}$ and $\mathrm{SiO}_{2}$, combusted under vacuum at $1100{ }^{\circ} \mathrm{C}$, and the resultant $\mathrm{SO}_{2}$ was cryogenically purified [86]. Isotope ratios in $\mathrm{SO}_{2}$ gas were measured on a modified VG602C gas source mass spectrometer. For O isotopes, $1 \mathrm{mg}$ $\mathrm{BaSO}_{4}$ was analyzed using a continuous-flow isotope ration mass spectrometer (Finnigan Delta X Plus) coupled with a thermal combustion elemental analyzer. Standardization is based on international standards NBS123 and OGS-1 (equivalent to NBS-127) [87]. Values of $\delta^{34} \mathrm{~S}$ and $\delta^{18} \mathrm{O}_{\mathrm{SO} 4}$ are reported relative to Vienna Canyon Diablo Triolite (VCDT) and Vienna Standard Mean Ocean Water (VSMOW), with analytical precisions of $0.13 \%$ o $(1 \sigma)$ and $0.4 \%$ o $(1 \sigma)$, respectively, according to repeated analysis of laboratory standards.

\section{Results}

The $\delta^{34} \mathrm{~S}$ and $\delta^{18} \mathrm{O}_{\mathrm{SO}}$ values of sulfate minerals, sulfate-rich sediment and water from playa lakes are listed in Supplementary Table S1. Figure 4 is a histogram of $\delta^{34} S$ values, and Figure 5 is a plot of $\delta^{34} \mathrm{~S}$ vs. $\delta^{18} \mathrm{O}_{\mathrm{SO} 4}$ for all samples with $\mathrm{O}$ isotope measurements. Values of $\delta^{34} \mathrm{~S}$ range from +4 to $+22 \%$ except for certain units in Safford Basin and deeply-buried evaporite at Bristol Dry Lake. Values of $\delta^{18} \mathrm{O}_{\mathrm{SO} 4}$ range from +3 to $+19 \%$. For individual sites, both $\delta^{34} \mathrm{~S}$ and $\delta^{18} \mathrm{O}_{\mathrm{SO} 4}$ values have much narrower ranges. Sulfate in present-day playas has a $\delta^{34} \mathrm{~S}$ range of +4 to $+10 \%$, except at White Sands, New Mexico, where the range in gypsum sand is +12 to $+14 \%$ [60], Estancia, +19 to $+21 \%$ [60] and Death Valley, +14 to $+19 \%$ o [59]. 

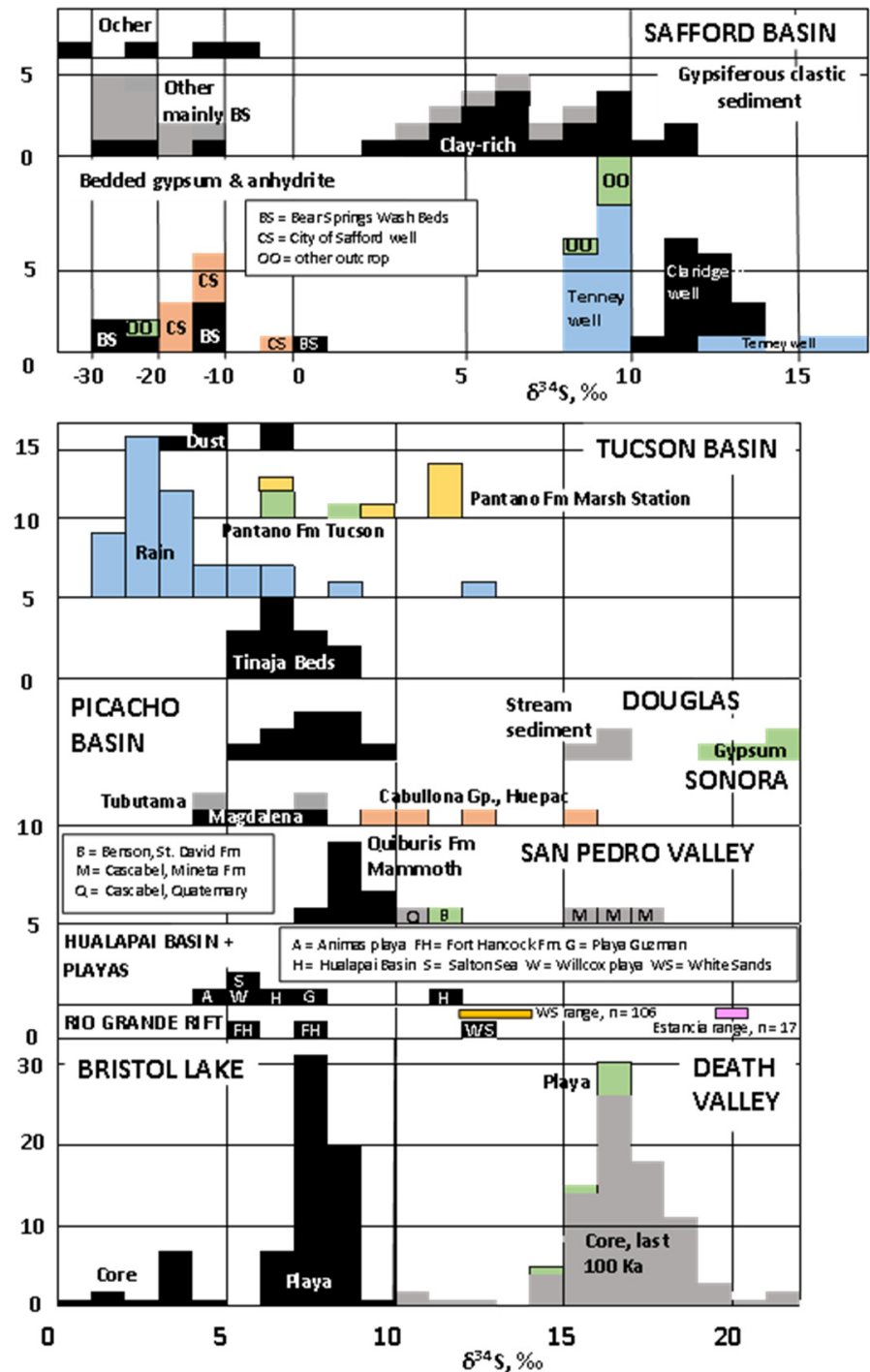

Figure 4. Histogram of $\delta^{34} \mathrm{~S}$ data for evaporites and playas, and data for rain and dust in Tucson Basin. Data are from this study, except: ranges for White Sands and Estancia Basin [60], Hualapai Basin [16], Bristol Dry Lake [57], Death Valley [59].

Many of the ancient evaporite sites have $\delta^{34} S$ values between +4 and $+10 \%$, including large-volume evaporites and gypsiferous sediment in Tucson, Picacho and Safford basins. Outliers with $\delta^{34} \mathrm{~S}>+10 \%$ include large-volume occurrences in Safford Basin (Claridge well and part of the Tenney well) and sulfate-rich sediment in Death Valley; small-volume gypsum bodies in this bracket occur at Douglas (+19 to $+22 \%$ ), Marsh Station in Tucson Basin ( +12 to $+13 \%$ o ) and Cascabel in the San Pedro Basin $(+11 \%$ and +16 to $+17 \%$ o $)$ Outliers with $\delta^{34} \mathrm{~S}<+4 \%$ include large gypsum bodies at depth below Bristol Dry Lake, California ( 0 to $+4 \%$ ) and in Safford Basin, gypsum intersected by the City of Safford well (mainly -20 to $-10 \%$ o ) and minor occurrences in the Bear Springs Wash Beds, $(-30$ to $-10 \%$ o . 


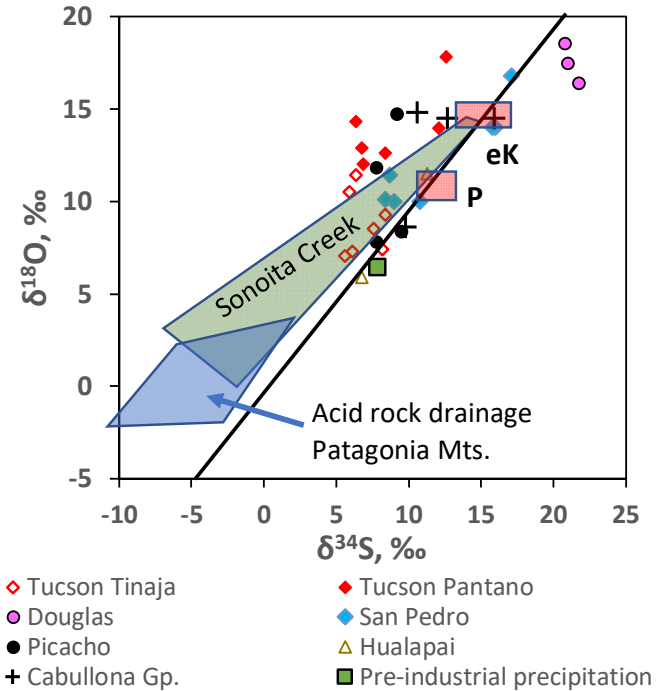

(a)

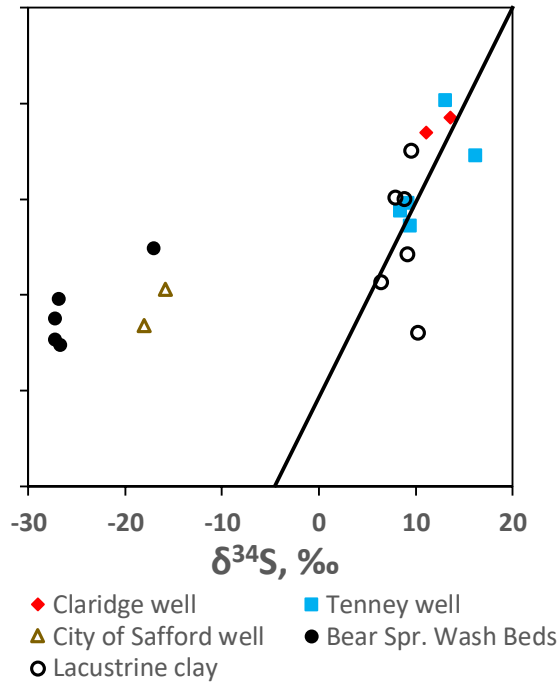

(b)

Figure 5. Plots of $\delta^{18} \mathrm{O}$ (sulfate) vs. $\delta^{34} \mathrm{~S}$ for sulfate minerals in evaporites and lacustrine sediments. (a) Arizona basins (except Safford) and Cabullona Group, Sonora; also shown are data for Sonoita Creek base flow and riparian groundwater, and acid rock drainage from the Patagonia Mountains (blue-shaded area). (b) Safford Basin. Black diagonal lines are $\delta^{34} S=\delta^{18} \mathrm{O}$. Data sources: Cabullona Group [81], Hualapai Basin [16], sulfate in pre-industrial precipitation [66], Sonoita Creek and Patagonia Mountains [63,69,70], other locations, this study.

Vertical variations of $\delta^{34} \mathrm{~S}$ and $\delta^{18} \mathrm{O}_{\mathrm{SO} 4}$ are present in the Tenney \#3 State well, Safford Basin, in which two separate gypsum layers appear to be present (Figure 6). Although depths of well cuttings cannot be correlated from one part of Safford Basin to another, occurrences of gypsum in the basin appear to indicate a complex evolution of isotopes over time. Vertical variations of $\delta^{34} \mathrm{~S}$ and $\delta^{18} \mathrm{O}_{\mathrm{SO} 4}$ are documented in Death Valley [59] (Figure 6) and of $\delta^{34} \mathrm{~S}$ at Bristol Dry Lake [57].

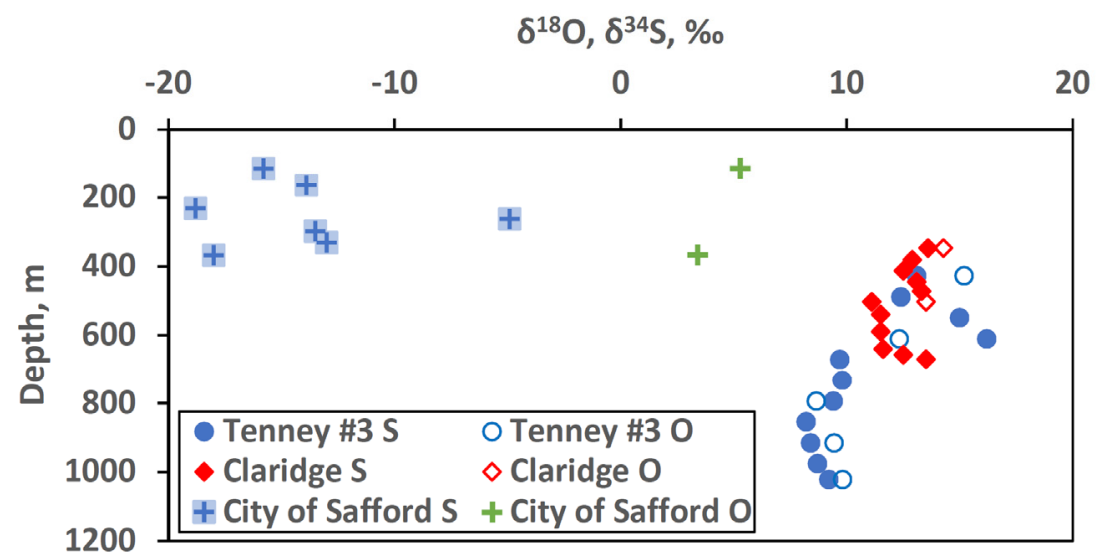

Figure 6. Values of $\delta^{34} \mathrm{~S}$ and $\delta^{18} \mathrm{O}$ (sulfate) in drill-cuttings from Safford Basin, as a function of depth below surface.

For gypsum with $\delta^{34} \mathrm{~S}>0 \%, \delta^{34} \mathrm{~S}$ and $\delta^{18} \mathrm{O}_{\mathrm{SO} 4}$ show a positive, linear correlation in Safford Basin (Figure 5b). Elsewhere, $\delta^{34} \mathrm{~S}$ and $\delta^{18} \mathrm{O}_{\mathrm{SO} 4}$ are scattered around the $\delta^{18} \mathrm{O}_{\mathrm{SO} 4}=\delta^{34} \mathrm{~S}$ line of the plot, much of the scatter arising in the minor gypsum occurrences at Marsh Station and Douglas. In the large gypsum accumulations of Picacho and Tucson Basins, some data plot near the line $\delta^{18} \mathrm{O}_{\mathrm{SO} 4}=\delta^{34} \mathrm{~S}$, and some above the line. 


\section{Discussion}

\subsection{Sources of Sulfur, Principal Controls}

With two exceptions, the bulk values of $\delta^{34} S$ in all evaporite deposits in the study area are lower than those of sulfate in Late Paleogene to Neogene marine evaporites, which have $\delta^{34} \mathrm{~S}$ values ranging from +21 to $+22 \%$ [ [4]. These values indicate that the evaporites are of non-marine origin. The exceptions, at Douglas and in the Estancia Basin [60], are forming at present in non-marine basins. No spatial zonation of $\delta^{34} S$ is present at regional scale.

In Figure 5, the data plot close to or above the line $\delta^{18} \mathrm{O}_{\mathrm{SO} 4}=\delta^{34} \mathrm{~S}$, except for the Douglas site where the sulfur source is local and unusual for the region (Section 4.4). The relationship with the line $\delta^{18} \mathrm{O}_{\mathrm{SO} 4}=\delta^{34} \mathrm{~S}$ can be compared with the mixing trend, also close to $\delta^{18} \mathrm{O}_{\mathrm{SO} 4}=\delta^{34} \mathrm{~S}$, of sulfate near the Patagonia Mountains [88]. Acid rock drainage with low values of $\delta^{34} \mathrm{~S}$ and $\delta^{18} \mathrm{O}_{\mathrm{SO} 4}$ mixes with basin groundwater containing reworked Permian marine sulfate in which $\delta^{34} \mathrm{~S}$ and $\delta^{18} \mathrm{O}_{\mathrm{SO} 4}$ are both near $+14 \%$ (Figure 5a). A similar trend is present in Tucson Basin groundwater [63]. Therefore, a principal regional control on sulfate isotopes appears to be the mixing of sulfur of Permian marine and bedrock sulfide sources. Mixing with marine sulfate is required, because the sulfur flux from PCDs has $\delta^{34} \mathrm{~S}$ and $\delta^{18} \mathrm{O}_{\mathrm{SO} 4}$ less than about $6.5 \%$ (Section 1.8). Cyclic recrystallization (Section 4.4) may explain the data above the line $\delta^{18} \mathrm{O}_{\mathrm{SO} 4}=\delta^{34} \mathrm{~S}$.

\subsection{Sources of Sulfur, Picacho Basin}

The 50 to $100 \mathrm{~km}^{3}$ anhydrite body in Picacho Basin requires a very large source of sulfur. The range of $\delta^{34} \mathrm{~S}$ in vertical profile, $4 \%$ (Supplementary Table S1), indicates relatively little change in the ratio of sulfur sources during deposition. Table 2 summarizes mass-balance requirements for sulfur, with different assumptions about sources. The average of available $\delta^{34} \mathrm{~S}$ data, $+7.8 \%$, might be explained by mixing about-equal amounts of sulfur from PCDs (bulk $\delta^{34} \mathrm{~S}=+3.3 \%$ ) and Permian marine gypsum $(+13 \%)$. The quantities required, multiple giant PCDs and 50 to $100 \mathrm{~km}^{3}$ of Permian gypsum, are unlikely to have been available in the immediate region around Picacho Basin as the evaporites accumulated, although larger volumes of Permian gypsum might have been available in the Colorado Plateau.

Table 2. Mass Balance of sulfur.

\begin{tabular}{|c|c|c|c|c|c|c|c|}
\hline Mineral & Volume & SG & Concentration & Amount & Mass S & & \\
\hline \multicolumn{3}{|c|}{$\mathrm{km}^{3}$} & & $10^{9} \mathrm{t}$ & $10^{9} \mathrm{t}$ & & \\
\hline Gypsum & 10 & 1.62 & $90 \% \mathrm{vol}^{*}$ & 14.6 & 2.7 & & \\
\hline Anhydrite & 10 & 2.97 & $90 \% \mathrm{vol} *$ & 26.7 & 6.2 & & \\
\hline \multicolumn{4}{|c|}{$\begin{array}{c}\text { Amount of Source Material Required for } 10 \mathrm{~km}^{3} \\
\text { of Evaporite }\end{array}$} & & & \multicolumn{2}{|c|}{ Required per $10 \mathrm{~km}^{3}$ of } \\
\hline \multirow{2}{*}{\multicolumn{3}{|c|}{ Material }} & \multirow{2}{*}{$\begin{array}{l}\text { Concentration } \\
\text { of S, ppm }\end{array}$} & & Mass S & anhydrite & gypsum \\
\hline & & & & & $10^{9} t$ & & \\
\hline \multicolumn{3}{|c|}{ Andesite, $10 \mathrm{~km}^{3}, \mathrm{SG}=2.7$} & 60 & & $0.0016 \#$ & $3.9 \times 10^{4} \mathrm{~km}^{3}$ & $1.7 \times 10^{4} \mathrm{~km}^{3}$ \\
\hline \multicolumn{3}{|c|}{ Giant PCD } & & & 1 & 6 PCDs & 3 PCDs \\
\hline \multicolumn{3}{|c|}{ Giant PCD + caprock } & & & $2 ?$ & 3 PCDs & 1-2 PCDs \\
\hline \multicolumn{3}{|c|}{$\begin{array}{l}\text { Present rainwater, } 300 \mathrm{~mm} / \mathrm{a} \text { over } \\
1000 \mathrm{~km}^{2} \text { catchment }\end{array}$} & 0.7 & & $0.2 / \mathrm{Ma}$ & $31 \mathrm{Ma}$ & $14 \mathrm{Ma}$ \\
\hline \multicolumn{8}{|c|}{ Required for Picacho anhydrite body } \\
\hline Volume, $\mathrm{km}^{3}$ & \multicolumn{3}{|c|}{ Assumed source of $S$} & \multicolumn{4}{|c|}{ Amount required } \\
\hline 50 & \multicolumn{3}{|c|}{$50 \%$ each from Permian gypsum and PCDs } & \multicolumn{4}{|c|}{$50 \mathrm{~km}^{3}$ Permian gypsum + 7.5 PCDs } \\
\hline 100 & \multicolumn{3}{|c|}{$50 \%$ each from Permian gypsum and PCDs } & \multicolumn{4}{|c|}{$100 \mathrm{~km}^{3}$ Permian gypsum +15 PCDs with caprock } \\
\hline 50 & \multicolumn{3}{|c|}{$\begin{array}{l}60 \% \text { each from Permian gypsum, } 40 \% \text { from } \\
\text { andesite }\end{array}$} & \multicolumn{4}{|c|}{$60 \mathrm{~km}^{3}$ Permian gypsum $+0.8 \times 10^{5} \mathrm{~km}^{3}$ andesite } \\
\hline 100 & \multicolumn{3}{|c|}{$\begin{array}{l}60 \% \text { each from Permian gypsum, } 40 \% \text { from } \\
\text { andesite }\end{array}$} & \multicolumn{4}{|c|}{$120 \mathrm{~km}^{3}$ Permian gypsum $+1.6 \times 10^{5} \mathrm{~km}^{3}$ andesite } \\
\hline 50 & \multicolumn{3}{|c|}{$100 \%$ from rainwater } & \multicolumn{4}{|c|}{15 Ma over $10^{5} \mathrm{~km}^{3}$ catchment } \\
\hline 100 & \multicolumn{3}{|c|}{$100 \%$ from rainwater } & \multicolumn{4}{|c|}{30 Ma over $10^{5} \mathrm{~km}^{3}$ catchment } \\
\hline
\end{tabular}


If Laramide andesite containing $60 \mathrm{ppm} \mathrm{S}$ with $\delta^{34} \mathrm{~S}=0 \%$ supplied the low- $\delta^{34} \mathrm{~S}$ endmember, about $40 \%$ of the total sulfur according to isotope balance, volumes of andesite of about $10^{5} \mathrm{~km}^{3}$ would be required if all $\mathrm{S}$ were extracted. In this case, a very large amount of clastic detritus would have to be accounted for.

Present-day rainwater in Tucson Basin contains $0.7 \mathrm{ppm} \mathrm{S}$ as sulfate [66]. If such rainwater collected over a catchment of $10^{5} \mathrm{~km}^{3}$, comparable to the area of the Basin-andRange province in southern Arizona, it would take 15 to 30 Ma to supply enough sulfur. The $\delta^{34} S$ value of ancient rain, $7.9 \%$, matches the bulk $\delta^{34} S$ of the evaporite body, but the chloride that would also be supplied in rainwater is missing. The large differences in $\delta^{34} \mathrm{~S}$ among sites for this study indicate that local geology is more important than regional atmospheric deposition in generating the isotope characteristics of the evaporite deposits.

Singly or in combination, the sulfur sources do not satisfactorily explain the evaporite accumulation in Picacho Basin or in Safford Basin where 33 to $67 \mathrm{~km}^{3}$ of gypsum may be present [22].

\subsection{Sources of Sulfur, Safford Basin}

Drill-core samples show stratification of $\delta^{34} \mathrm{~S}$ and $\delta^{18} \mathrm{O}_{\mathrm{SO} 4}$ (Figures $5 \mathrm{~b}$ and 6 ). In the Tenney \#3 State well, $\delta^{34} \mathrm{~S}$ values are +10 to $+17 \%$ (type A) from 347 to $670 \mathrm{~m}$ below surface, and +8 to $+10 \%$ (type B) below $670 \mathrm{~m}$. Although sediment depths cannot be correlated with certainty between drill sites, type A gypsum in the Claridge and Tenney wells may be of the same age. Types A and B plot close to the line $\delta^{18} \mathrm{O}_{\mathrm{SO} 4}=\delta^{34} \mathrm{~S}$ (Figure 6), consistent with the mixing of sulfur of PCD and Permian or Early Cretaceous marine origins. In this case, the sulfur sources appear to have evolved over time, from marine + PCD in type B to marine alone in type A.

The City of Safford well $\left(\delta^{34} S\right.$ from -18 to $-5 \%$ ), which penetrates down-faulted strata close to the basin center, and outcrop of the Bear Springs Wash Beds, BSWB $\left(\delta^{34} \mathrm{~S}\right.$ from -30 to $+10 \%$ ) contain gypsum of a third type, C. The $\delta^{18} \mathrm{O}_{\mathrm{SO} 4}$ values range from +2.4 to $+7.5 \%$ (Figure $5 b$ ), higher than values that arise from oxidation of sulfide elsewhere in the region, e.g., $0 \pm 1 \%$ in Tucson Basin (Table 1). The higher $\delta^{18} \mathrm{O}_{\mathrm{SO} 4}$ values in Safford Basin may reflect the participation of evaporated lake water [40]. In the BSWB, type C occurs as thin gypsum beds and as dispersed sulfate in clastic sediments and ocher along the northeastern flank of the Pinaleno Mountains (Supplementary Figure S2). Thin (a few $\mathrm{cm}$ ) sulfide-bearing beds weathering to Fe sulfates are present in outcrop. Oxidation of similar sulfide appears to be the source of the gypsum with $\delta^{34} S$ values $<-25 \%$ in the BSWB. The range of $\delta^{34} S$ in the City of Safford well cuttings can be explained by mixing of sulfate derived from sulfides with sulfate of type A and B. Gypsum in the well cuttings may include 25 to $30 \%$ of sulfide-sulfur according to isotope balance.

The amount of sulfide visible in outcrop of the BSWB is small and appears insufficient to account for the $267 \mathrm{~m}$ of low- $\delta^{34} \mathrm{~S}$ massive gypsum in the City of Safford well. A possible explanation for the low- $\delta^{34} \mathrm{~S}$ sulfate in the well cuttings may be found in the formation (13-4 Ma) and subsequent erosion of the supergene enrichment blanket overlying the giant Morenci PCD in the Gila River catchment about $40 \mathrm{~km}$ upstream of Safford Basin. Supergene enrichment is a near-surface weathering process occurring at about $25^{\circ} \mathrm{C}$ near the water table [89]; therefore BSR is possible but not TSR [53]. The few measurements available for the deposit are consistent with primary sulfide $\delta^{34} S$ near $0 \%$, and supergene sulfide with a $\delta^{34} \mathrm{~S}$ range of -31 to $0 \%$ as a result of BSR, for which textural evidence is present [72]. At the PCD, supergene enrichment may initially have released sulfate with $\delta^{34} \mathrm{~S}>0 \%$ (contributing to types A and B) during the formation stage, leaving residual sulfide with low $\delta^{34} \mathrm{~S}$ values in the supergene ore of the deposit. Subsequent erosion of the supergene ore may have released sulfate with $\delta^{34} \mathrm{~S}<0 \%$ (contributing to type $\mathrm{C}$ ). The occurrence of type $C$ gypsum at $95-367 \mathrm{~m}$ below surface, in contrast to types A and B at 329-1037 m (Supplementary Table S1) appears consistent with this explanation. Safford Basin is the only example in which a large-scale contribution of BSR to evaporite sulfate in the study area is probable. 


\subsection{Sources of Sulfur, Gypsum with $\delta^{34} S>10 \%$}

Gypsum in the White Sands playa and dune-field, New Mexico, has $\delta^{34} \mathrm{~S}$ values of 12 to $13 \%$ [60], readily explained by reworking of Permian marine gypsum in nearby strata [90]. In the Estancia gypsum dune-field, New Mexico, subjacent Permian gypsum is also the main source of sulfate [60], but dune sand has a $\delta^{34} S$ range of +19 to $+21 \%$. The authors attributed the increase in $\delta^{34} S$ to BSR in the groundwater system feeding the Estancia playa.

The sulfur source for the small gypsum occurrence near Douglas, Arizona, is pyritic limestone in D Hill. Three samples of the pyrite had $\delta^{34} S$ values of $+3.8,+10.9$ and $+21.2 \%$. Dry stream sediment on the hill slopes preserves sulfate that provides a better estimate, +15.5 to $+16.8 \%$, of average $\delta^{34} \mathrm{~S}$ in runoff from the hill. The gypsum has $\delta^{34} \mathrm{~S}$ values of +20.8 to $+21.8 \%$. Values of $\delta^{18} \mathrm{O}_{\mathrm{SO} 4}$ increase as $\delta^{34} \mathrm{~S}$ increases (Supplementary Table S1). BSR is unlikely, because gypsum is forming in near-surface sediment that is usually dry. The occurrence of coarse-grained, clear gypsum crystals indicates recrystallization, possibly affecting some of the gypsum each wet season. A stream-sediment sample with $\delta^{34} \mathrm{~S}$ and $\delta^{18} \mathrm{O}_{\mathrm{SO}}$ values of $+15.5 \%$ and $+3.3 \%$, respectively, may be close to unevolved sulfate formed by weathering of pyrite because of its low $\delta^{18} \mathrm{O}_{\mathrm{SO} 4}$ value. This sample provides the starting point for Rayleigh fractionation modeling of isotope fractionation arising from cyclic recrystallization (Figure 7). The array of samples from Douglas could be explained by repeated dissolution and crystallization of sulfate with $\delta^{18} \mathrm{O}_{\mathrm{SO} 4}$ near $+3 \%$ and $\delta^{34} \mathrm{~S}$ of +12 to $+15.5 \%$. The residual gypsum samples would represent only about $2 \%$ of the original sulfate. Repeated loss of sulfate from the system is plausible because it is open to groundwater flow to the northwest.

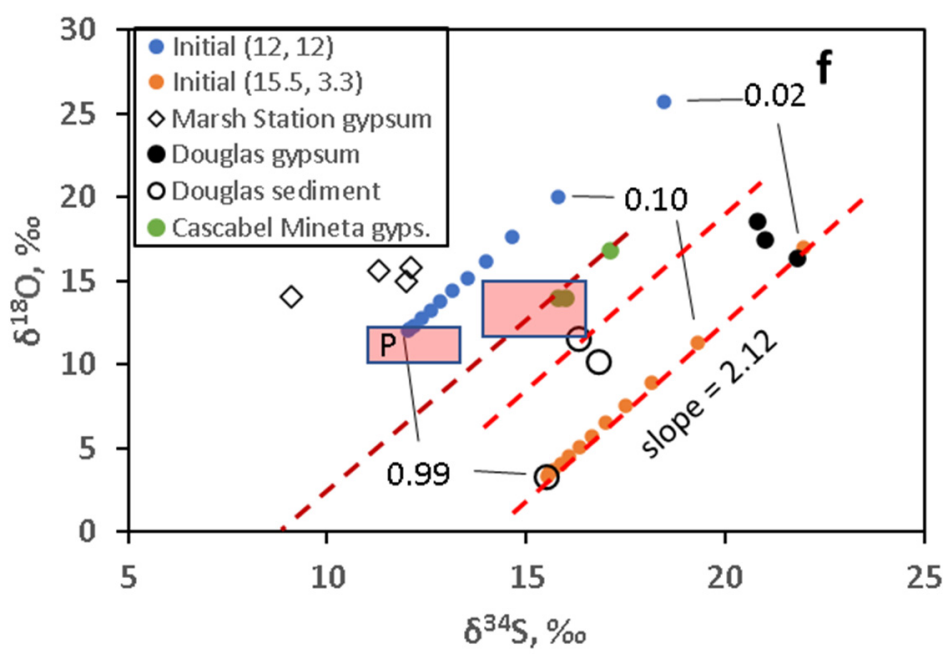

Figure 7. Plots of $\delta^{18} \mathrm{O}$ (sulfate) vs. $\delta^{34} \mathrm{~S}$ in gypsum, where fractionation is due to cyclic dissolution and recrystallization with loss of some aqueous sulfate in each cycle. The theoretical values (colored points) were calculated from chosen starting points, using fractionation factors from [47,48]. " $\mathrm{f}$ " represents the fraction of original sulfate remaining as gypsum.

At Marsh Station, most of the $\delta^{34} S$ values plot close to those of Permian sulfate $(+12$ to $+13 \%$ ), but values of $\delta^{18} \mathrm{O}_{\mathrm{SO} 4}$ are about $+15 \%$. Inorganic recrystallization starting from $(+12,+12 \%)$ does not explain the $\delta^{18} \mathrm{O}_{\mathrm{SO} 4}$ values (Figure 7$)$. In this case, gypsum occurs as nodules in gray mud, and BSR may have affected aqueous sulfate prior to gypsum formation, but from a starting material that was not Permian marine sulfate.

At Cascabel, data for gypsum from the Mineta Formation appear to form a recrystallization trend (Figure 7). The gypsum retains bedding structure but is strongly recrystallized and occurs in strata with evidence of hydrothermal circulation (bleaching of $\mathrm{Fe}^{3+}$ oxides, local deposition of pyrite). The lowest values of $\delta^{34} \mathrm{~S}$ and $\delta^{18} \mathrm{O}_{\mathrm{SO} 4}$ fall within the field of Early Cretaceous marine sulfate [4], a possible source. An Early Cretaceous marine 
transgression represented by Mural Limestone, part of the Bisbee Group, extended to a coastline at most $15 \mathrm{~km}$ south of the gypsum outcrop [91]. In the immediate area of the gypsum, the depositional environment of the Bisbee Group was subaerial [92]. Textural evidence of sulfate minerals in the Mural Limestone is rare [93], but survival of marine sulfate in connate water is not precluded.

\subsection{Bristol Dry Lake and Death Valley}

These occurrences differ from those in the Basin and Range Province in Arizona in the abundance of halite, and in the case of Death Valley [59], the presence of highly-soluble sulfate minerals glauberite and thenardite, exceeding gypsum in abundance. At Bristol Dry Lake, BSR was suggested to explain low values of $\delta^{34} S$ in gypsum from drill core beneath the present playa, implicitly assuming constant $\delta^{34} S$ in sulfate supplied to the basin [57]. BSR is implausible because it is difficult to decrease the $\delta^{34} S$ of residual gypsum by that means. Gypsum in the sample set ranges from 3.5 Ma old to Holocene; a change in sulfate source over time seems a more likely explanation.

At Death Valley, $\delta^{34} \mathrm{~S}$ of sulfate ranges from +5 to $+22 \%$ (Figure 8 ) in sediment dating from the past $200 \mathrm{Ka}$ [59]. The authors explained the range of $\delta^{34} \mathrm{~S}$ by changes in the relative importance of three sources, atmospheric deposition $(+7 \%$ o), local groundwater $(+16$ to $+18 \%$ ) and regional groundwater $(+21 \%$ o), the changes mediated by long-term variations in rainfall amount. Such an explanation may hold for long core intervals in which $\delta^{34} S$ has small ranges, but is less satisfactory for other core intervals with large ranges of $\delta^{34} S$ and fluctuations observed at a scale of 5 to $20 \mathrm{~cm}$. BSR acting in small, closed-system cells may explain the latter core intervals. The sulfate occurs in soluble minerals and is or was available to bacteria. At 110 to $120 \mathrm{~m}$ depth, persistent $\delta^{34} \mathrm{~S}$ values of +5 to $+7 \%$ o may correspond to the dominant sulfate source at the time (a period of halite deposition), and higher values of $\delta^{34} S$ to sulfate remaining after BSR.

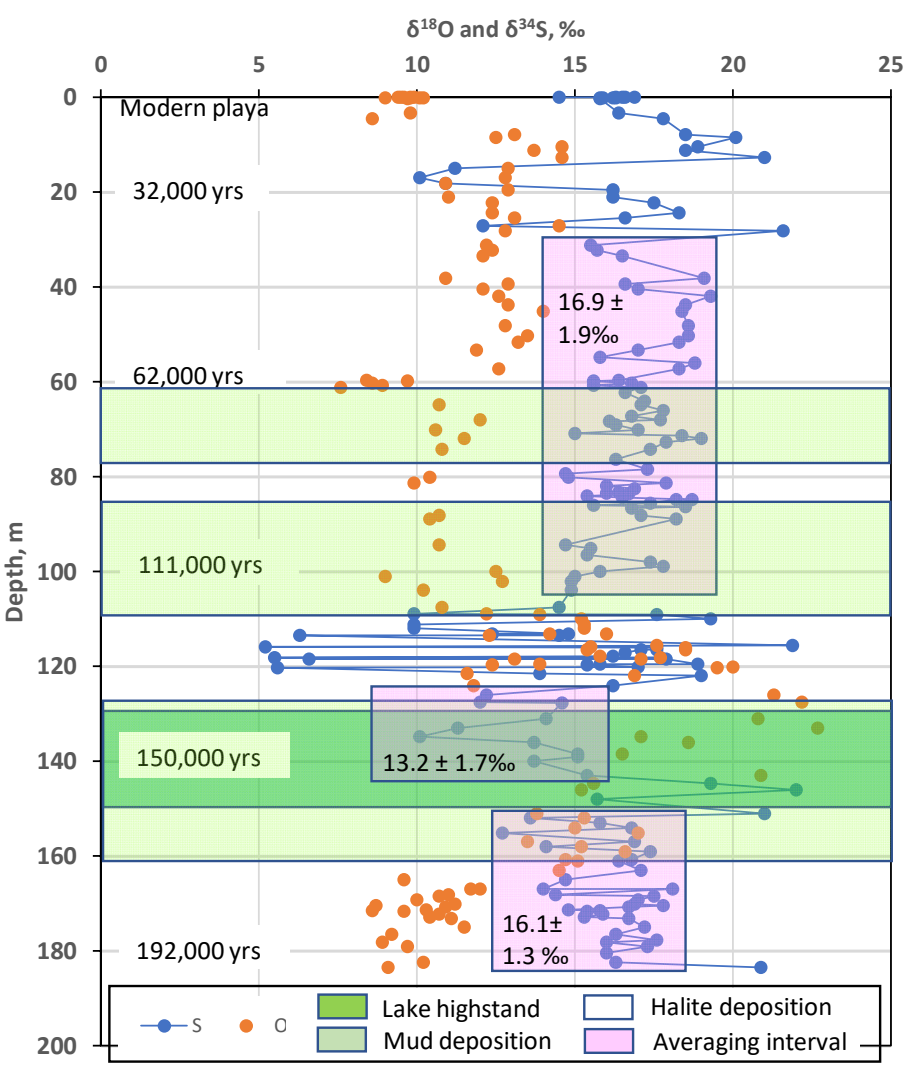

Figure 8. Values of $\delta^{34} \mathrm{~S}$ and $\delta^{18} \mathrm{O}$ (sulfate) in drill-cuttings from Badwater, Death Valley, California as a function of depth below surface and sediment age. Data source, including paleoenvironmental interpretations [59]. 


\subsection{Episodes of Evaporite Formation}

It has been assumed above that all sulfur in the larger evaporite bodies originated from bedrock weathered at the time of Basin-and-Range extension that began about $15 \mathrm{Ma}$ ago in southern Arizona. Older gypsum exists in the region: in the Mineta Formation of Oligocene age, in the Magdalena and Tubutama Formations of Early Miocene (about $22 \mathrm{Ma}$ ) age [17] in Sonora, Mexico, in the mid-Miocene or older Pantano Formation [33] of Tucson Basin, Arizona and dispersed in lacustrine sediments of the syn-volcanic Late Cretaceous Cabullona Group [80] at Huépac, Sonora [81]. These have isotope characteristics like those of the Basin-and-Range evaporites (Figures 4 and $5 \mathrm{a}$ ). This suggests mixing of igneous or PCD and marine sulfur in non-marine sediment of the Cordillera over a protracted interval. Sulfate accumulated in the deep troughs of the Basin and Range Province may partly represent re-working of earlier non-marine evaporites, the salts progressively moving towards the deepest depressions. The need for very large sources of sulfur in the Picacho and Safford Basins stands, but the sources may be distributed widely in space and time.

\subsection{Evaporite Evolution}

The near absence of halite in large sulfate accumulations in Picacho and Tucson Basins, was noted as a problem in Section 4.2. A related problem applies in the Hualapai and Luke Basins, where large halite accumulations with little sulfate occur [16,23]. Even if the sulfate evaporites mainly result from weathering of sulfur-rich, chloride-poor bedrock, some chloride is supplied in dust and rainwater, as observed in present-day halite enrichment in Tucson Basin soil profiles [64]. Cyclic reworking of evaporites could separate chloride from sulfate. An evaporite deposit about to be eroded may lose halite to groundwater before gypsum becomes mobile because of the greater solubility of halite; such a separation is occurring at present where Permian marine halite of the Holbrook Basin, northeastern Arizona, is dissolving into superjacent groundwater [94]. Permanent separation of chloride and sulfate remains difficult, the solubility difference notwithstanding. Chloride-bearing groundwater would need to flow into a downgradient basin before substantial transport of sulfate occurred. Dewatering of gypsum to form anhydrite would have provided abundant hot water to leach halite, and could have transported the chloride into the Luke Basin from the Picacho and Chandler Basins, $115 \mathrm{~km}$ and $50 \mathrm{~km}$ to the southeast, respectively.

The Death Valley lacustrine deposits in California provide an example of rift-basin evaporite that has undergone little modification through interaction with groundwater. The strata retain halite, soluble Na sulfates and a complex, fine-scale layering of $\delta^{34} \mathrm{~S}$ and $\delta^{18} \mathrm{O}_{\mathrm{SO} 4}$. Original large evaporite deposits in southern Arizona were most likely of similar nature, prior to reworking by groundwater.

\subsection{Study Significance and Future Research}

This study highlights the complexity of sulfur geochemistry in a tectonically-active continental region in which interior basins have formed and eroded over 100 million years, and in which basins have at times been closed and at others hydraulically connected. Similar complex evolution is likely in other active orogenic zones. The large sizes and non-marine isotope compositions of several of the evaporite deposits indicate that their potential contribution to surface water and groundwater should be considered in addition to regional marine evaporites when $\delta^{34} \mathrm{~S}$ is used in weathering budget calculations.

Several questions remain inadequately answered, e.g.,: (1) What are the bulk value of $\delta^{34} \mathrm{~S}$ and the total sulfur content in PCDs of the study area? (2) What mechanisms separate sulfate and chloride as evaporites are deposited and reworked? (3) Why is there an apparent discrepancy between the size of sulfate evaporites and local sources of sulfur? (4) What is the sulfur content and sulfur isotope composition in certain major bedrock units in this region? Larger datasets are required in order to address such questions. This will be possible for numbers (1), (3) and (4). Question (2) requires detailed studies of basin development, which may prove difficult because collections of twentieth-century drill-core cuttings have been discarded since the initiation of this study. 


\section{Conclusions}

1. Cenozoic gypsum and anhydrite evaporites in southwest North America have $\delta^{34} S$ values ranging from 0 to $+22 \%$, except in a limited area of Safford Basin, for which the range is -30 to $-10 \%$. Most $\delta^{34} S$ values fall within the range +4 to $+10 \%$. The range of $\delta^{18} \mathrm{O}_{\mathrm{SO} 4}$ is +3 to $+19 \%$.

2. The evaporites are non-marine in origin, on the basis of their isotope values and geological setting.

3. A linear relationship between $\delta^{18} \mathrm{O}_{\mathrm{SO} 4}$ and $\delta^{34} \mathrm{~S}$, evident in the Sonoita Creek Basin [89], is a principal control of sulfate isotope composition in most of the evaporites, and is consistent with mixing between sulfate from Permian or Cretaceous marine gypsum with sulfate from weathered bedrock sources such as Laramide igneous rocks and associated porphyry copper deposits.

4. The isotope composition of sulfate from which gypsum formed remained about constant in certain large deposits in Tucson and Picacho Basins but changed greatly over time in Safford Basin.

5. Evaporites with $\delta^{34}$ S greater than $+10 \%$ mostly derived sulfur from Permian marine gypsum, e.g., at White Sands and Estancia, New Mexico [60] and Safford and Marsh Station (this study). Re-worked Early Cretaceous marine sulfate may be present in the Safford and San Pedro Basins. A minor evaporite at Douglas, Arizona, is deriving sulfur from pyritic limestone, and may have evolved to high $\delta^{18} \mathrm{O}_{\mathrm{SO} 4}$ and $\delta^{34} \mathrm{~S}$ values through cyclic recrystallization.

6. Bacterial sulfate reduction influenced sulfate isotopes strongly in few cases: Estancia, New Mexico [60] and possibly in limited stratigraphic intervals at Death Valley, California In Safford Basin, BSR led to deposition of pyrite in an anoxic lake, but of insufficient amount to account for a large volume of low- $\delta^{34} S$ gypsum in the basin. BSR operating during formation of a supergene enrichment blanket at a nearby porphyry copper deposit may have provided sufficient low- $\delta^{34} \mathrm{~S}$ sulfate.

7. The amount of sulfur in large evaporite bodies in southern Arizona is larger than can be explained by weathering of source rock at the time of deposition of the bodies. Long-term reworking of earlier non-marine evaporites may have occurred.

Supplementary Materials: The following are available online at https:/ / www.mdpi.com/article/ 10.3390/geosciences11110455/s1, Figure S1: Satellite image of Tucson Basin, Arizona, showing sample sites; Figure S2: Satellite image of Safford Basin, Arizona, showing sample sites; Figure S3: Satellite image of an un-named basin east of Douglas, Arizona, showing sample sites; Table S1: Sample locations and new isotope data.

Author Contributions: Conceptualization, A.G. and C.J.E.; methodology, A.G. and C.J.E.; validation, A.G. and C.J.E.; formal analysis, A.G.; investigation, A.G.; resources, A.G. and C.J.E.; data curation, A.G.; writing-original draft preparation, A.G. and C.J.E.; writing-review and editing, A.G. and C.J.E.; supervision, C.J.E.; project administration, C.J.E.; funding acquisition, A.G. All authors have read and agreed to the published version of the manuscript.

Funding: This research was funded by the Laboratory of Isotope Geochemistry, Department of Geosciences, University of Arizona. ChevronTexaco Co. provided additional financial support to A.G. through its summer scholarship program.

Data Availability Statement: All new data have been made available in the article.

Acknowledgments: We are grateful for support from the late Austin Long, director of the Laboratory of Isotope Geochemistry at the time of the study. Raymond Harris (Arizona Geological Survey) was very helpful in providing archived well cutting samples and helping us to locate outcrop. Useful discussions with Spencer Titley, Eric Seedorff and Victor Valencia are gratefully acknowledged. We thank three anonymous reviewers for their constructive comments.

Conflicts of Interest: The authors declare no conflict of interest. External funders had no role in the design of the study; in the collection, analyses, or interpretation of data; in the writing of the manuscript, or in the decision to publish the results. 


\section{References}

1. Eckardt, F.D. The origin of sulphates: An example of sulphur isotopic applications. Prog. Phys. Geog. 2001, 25, 512-519. [CrossRef]

2. Pearson, F.J.; Rightmire, C.T. Sulfur and oxygen isotopes in aqueous sulfur compounds. In Handbook of Environmental Isotope Geochemistry, Vol. 1, The Terrestrial Environment A; Fritz, P., Fontes, J.C., Eds.; Elsevier: Amsterdam, The Netherlands, 1980; pp. 227-258.

3. Krouse, H.R.; Grinenko, V.A. Stable Isotope, Natural and Anthropogenic Sulphur in the Environment (SCOPE Series); John Wiley: Hoboken, NJ, USA, 1991.

4. Claypool, G.E.; Holser, W.T.; Kaplan, I.R.; Sakai, H.; Zak, I. The age curves of sulfur and oxygen isotopes in marine sulfate and their mutual interpretation. Chem. Geol. 1980, 28, 199-260. [CrossRef]

5. Utrilla, R.; Pierre, C.; Orti, F.; Pueyo, J.J. Oxygen and sulphur isotope compositions as indicators of the origin of Mesozoic and Cenozoic evaporates from Spain. Chem. Geol. 1992, 102, 229-244. [CrossRef]

6. Attia, O.E.; Lowenstein, T.K.; Wali, S.M.A. Middle Miocene gypsum, Gulf of Suez: Marine or non-marine? J. Sed. Res. 1995, A65, 614-626.

7. Palmer, M.; Helvaci, C.; Fallick, A.E. Sulphur, sulphate oxygen and strontium isotope composition of Cenozoic Turkish evaporites. Chem. Geol. 2004, 209, 341-356. [CrossRef]

8. Fontes, J.C.; Letolle, R. ${ }^{18}$ Oand $^{34} \mathrm{~S}$ in the Upper Bartonian gypsum deposits of the Paris basin. Chem. Geol. 1976, 18, 285-295. [CrossRef]

9. Chivas, A.R.; Andrew, A.S.; Lyons, W.B.; Bird, M.I.; Donnelly, T.H. Isotopic constraints on the origin of salts in Australian playas. 1. Sulphur. Palaeogeogr. Palaeoclimatol. Palaeoecol. 1991, 84, 309-322. [CrossRef]

10. Eckardt, F.D.; Spiro, B. The origin of sulphur in gypsum and dissolved sulphate in Central Namib Desert, Namibia. Sed. Geol. 1999, 123, 255-273. [CrossRef]

11. Holser, W.T.; Kaplan, I.R. Isotope geochemistry of sedimentary sulfates. Chem. Geol. 1966, 1, 93-135. [CrossRef]

12. Eugster, H.P. Geochemistry of evaporitic lacustrine deposits. Ann. Rev. Earth Plan. Sci. 1980, 8, 35-63. [CrossRef]

13. Fenneman, N.M. Physiography of Western United States, 1st ed.; McGraw-Hill: New York, NY, USA, 1931.

14. Peirce, H.W. Tectonic significance of Basin and Range thick evaporite deposits. Ariz. Geol. Soc. Digest 1976, 10, 325-339.

15. Bohannon, R.C. Nonmarine Sedimentary Rocks of Tertiary Age in the Lake Mead Region, Southwestern Nevada and Northwestern Arizona; US Geological Survey Professional Paper 1259; United States Government Publishing Office: Washington, DC, USA, 1984.

16. Faulds, J.E.; Schreiber, B.C.; Reynolds, S.J.; Gonzalez, L.A.; Maya, D. Origin and paleography of an immense, nonmarine Miocene salt deposit in the Basin and Range (Western USA). J. Geol. 1997, 105, 19-36. [CrossRef]

17. Miranda-Gasca, M.A.; Gomez-Caballero, J.A.; Eastoe, C.J. Borate deposits of northern Sonora, Mexico: Stratigraphy, tectonics, stable isotopes, and fluid inclusions. Econ. Geol. 1998, 93, 510-523. [CrossRef]

18. Fisher, R.S.; Mullican, W.F., III. Integration of Ground-Water and Vadose-Zone Geochemistry to Investigate Hydrochemical Evolution: A Case Study in Arid Lands of Northern Chihuahuan Desert, Trans-Pecos Texas; Geological Circular 90-5; Bureau of Economic Geology, University of Texas at Austin: Austin, TX, USA, 1990.

19. Buck, B.J.; Van Hoesen, J.G. Assessing the applicability of isotopic analysis of pedogenic gypsum as a paleoclimate indicator, southern New Mexico. J. Arid Environ. 2005, 60, 99-114. [CrossRef]

20. Eberly, D.; Stanley, B., Jr. Cenozoic stratigraphy and geological history of southwestern Arizona. Geol. Soc. Am. Bull. 1978, 89, 921-940. [CrossRef]

21. Anderson, S.R. Cenozoic Stratigraphy and Geologic History of the Tucson Basin, Pima County, Arizona; US Geological Survey WaterResources Investigations Reports 874190; Department of the Interior, US Geological Survey: Reston, VA, USA, 1987.

22. Harris, R.C. Distribution of Evaporites and Implications for Water Quality in the San Carlos-Safford-Duncan non-Point Source Management Zone; Arizona Geological Survey Open-File Report 97-03; Arizona Geological Survey: Tucson, AZ, USA, 1997.

23. Eaton, G.P.; Peterson, D.L.; Schumann, H.H. Geophysical, Geohydrological, and Geochemical Reconnaissance of the Luke Salt Body, Central Arizona; US Geological Survey. Professional Paper 753; United States Government Publishing Office: Washington, DC, USA, 1972.

24. Dean, W.E.; Johnson, K.S. Anhydrite Deposits of the United States and Characteristics of Anhydrite Important for Storage of Radioactive Wastes; US Geological Survey Bulletin 1974; US Geological Survey: Reston, VA, USA, 1989.

25. Richard, S.M.; Shipman, T.C.; Greene, L.C.; Harris, R.C. Estimated Depth to Bedrock in Arizona; Arizona Geological Survey Digital Geologic Map DGM-52; Arizona Geological Survey: Tucson, AZ, USA, 2007.

26. Dickinson, W.R. The Basin and Range Province as a composite extensional domain. Int. Geol. Rev. 2002, 44, 1-38. [CrossRef]

27. Anderson, T.W.; Freethey, G.W.; Tucci, P. Geohydrology and Water Resources of Alluvial Basins in South-Central Arizona and Parts of Adjacent States; US Geological Survey. Professional Paper 1406 B; United States Government Printing Office: Washington, DC, USA, 1992.

28. Peirce, H.W. Thick evaporites in the Basin and Range Province-Arizona. In 4th Symposium on Salt; Northern Ohio Geological Society: Cleveland, OH, USA, 1974; pp. 47-55.

29. Oppenheimer, J.M.; Sumner, J.S. Gravity modeling of the basins in the Basin and Range Province, Arizona. Ariz. Geol. Soc. Digest 1981, 13, 111-115.

30. Pool, D.R.; Carruth, R.L.; Meehan, W.D. Hydrogeology of Picacho Basin, South-Central Arizona; US Geological Survey Water-Resources Investigations Reports. 00-4277; United States Government Printing Office: Washington, DC, USA, 2001. 
31. Dickinson, W.R. Facies Map of Post-Mid-Miocene Quiburis Formation, San Pedro trough, Pinal, Pima, Gila, Graham, and Cochise Counties, Arizona; Arizona Geological Survey Contributed Map CM-98-A; Arizona Geological Survey: Tucson, AZ, USA, 1998.

32. Gray, R.S. Late Cenozoic Sediments in the San Pedro Valley Near St. David, Arizona. Master's Thesis, University of Arizona, Tucson, AZ, USA, 1965.

33. Dickinson, W.R. Tectonic Setting of Faulted Tertiary Strata Associated with the Catalina Core Complex in Southern Arizona; Geological Society of America Special Paper 264; Geological Society of America: Boulder, CO, USA, 1991.

34. Kruger, J.M. Seismic Crustal Structure Beneath the Safford Basin and Pinaleno Mountains: Implications for Cenozoic Extension and Metamorphic Core Complex Uplift in SE Arizona. Ph.D. Thesis, University of Arizona, Tucson, AZ, USA, 1991.

35. Kruger, J.M.; Johnson, R.A.; Houser, B.B. Miocene-Pliocene half-graben evolution, detachment faulting and late-stage core complex uplift from reflection seismic data in southeast Arizona. Basin Res. 1995, 7, 129-149. [CrossRef]

36. Houser, B.B. Late Cenozoic stratigraphy and tectonics of the Safford, Tonto, and Payson basins, southeastern and central Arizona. In Geological Excursions through the Sonoran Desert Region, Arizona and Sonora; Arizona Geological Survey Special Paper 7; Gehrels, G.E., Spencer, J.E., Eds.; Arizona Geological Survey: Tucson, AZ, USA, 1990; pp. 20-24.

37. Houser, B.B.; Richter, D.H.; Shafiqullah, M. Geological Map of the Safford Quadrangle, Graham County, Arizona; US Geological Survey Misc. Inv. Ser. Map 1-1617; United States Government Printing Office: Washington, DC, USA, 1985.

38. Schreiber, B.C.; Hsu, K.J. Evaporites. In Developments in Petroleum Geology; Vol. 2. Hobson, G.D., Ed.; Applied Science Publishers: Essex, UK, 1980; Volume 2, pp. 87-138.

39. Bobst, A.L.; Lowenstein, T.K.; Jordan, T.E.; Godfrey, L.V.; Ku, T.L.; Luo, S. A 106ka paleoclimate record form drill core of the Salar de Atacama, northern Chile. Palaeogeogr. Palaeoclimatol. Palaeoecol. 2001, 173, 21-42. [CrossRef]

40. Seal, R.R.; Alpers, C.N.; Rye, R.O. Stable isotope systematics of sulfate minerals. Rev. Mineral. Geochem. 2000, 40, 541-602. [CrossRef]

41. Stumm, W.; Morgan, J.J. Aquatic Chemistry; Wiley-Interscience: New York, NY, USA, 1970.

42. Ehrlich, H.L. Geomicrobiology; Marcel Dekker, Inc.: New York, NY, USA, 1981.

43. Taylor, B.E.; Wheeler, M.C.; Nordstrom, D.K. Isotope composition of sulphate in acid mine drainage as measure of bacterial oxidation. Nature 1984, 308, 538-541. [CrossRef]

44. Kroopnick, P.; Craig, H. Atmospheric oxygen: Isotopic composition and solubility fractionation. Science 1972, 175, 54-55. [CrossRef] [PubMed]

45. Peryt, T.M.; Bula, Z.; Halas, S.; Olszewska, B.; Pluta, I.; Slodkowska, B. Non-marine evaporites in the lower Miocene of Upper Silesia (Carpathian foreland basin, Poland). Geol. Carpathica 2005, 56, 327-336.

46. Chiba, H.; Sakai, H. Oxygen isotopic exchange rate between dissolved and water at hydrothermal temperatures. Geochim. Cosmochim. Acta 1985, 49, 993-1000. [CrossRef]

47. Thode, H.G.; Monster, J. Sulfur isotope geochemistry of petroleum, evaporites, and ancient seas. In Fluids in Subsurface Environment. Am. Assoc. Petrol. Geol. Mem. 1965, 4, 367-377.

48. Lloyd, R.M. Oxygen isotope behavior in the sulfate-water system. J. Geophys. Res. 1996, 73, 6099-6110. [CrossRef]

49. Van Driessche, A.E.S.; Canals, A.; Ossorio, M.; Garcia-Ruiz, J.M. New determination of gypsum isotope fractionation factor. Revista de la Sociedad Española de Mineralogía 2014, 19. Available online: http://diposit.ub.edu/dspace/handle/2445/97250 (accessed on 29 October 2021).

50. Eastoe, C.J. Stable chlorine isotopes in arid non-marine basins: Instances and possible fractionation mechanisms. Appl. Geochem. 2016, 74, 1-12. [CrossRef]

51. Worden, R.H.; Smalley, P.C.; Fallick, A.E. Sulfur cycle in buried evaporites. Geology 1997, 25, 643-646. [CrossRef]

52. Trudinger, P.A. Bacterial sulfate reduction: Current status and possible origin. In Early Organic Evolution: Implications for Mineral and Energy Resources: Proceedings of the 9th Alfred Wegener Conference; Schidlowski, M., Golubic, S., Kimberley, M.M., McKirdy, D.M., Trudinger, P.A., Eds.; Springer: Berlin/Heidelberg, Germany, 1992; pp. 367-378.

53. Machel, H.G. Bacterial and thermochemical sulfate reduction in diagenetic settings: Old and new insights. Sed. Geol. 2001, 140, 143-175. [CrossRef]

54. Ostroff, A.G. Conversion of gypsum to anhydrite in aqueous salt solutions. Geochim. Cosmochim. Acta 1964, $28,1363-1372$. [CrossRef]

55. Brunner, B.; Bernasconi, S.M.; Kleikemper, J.; Schroth, M.H. A model for oxygen and sulfur isotope fractionation in sulfate during bacterial sulfate reduction processes. Geochim. Cosmochim. Acta 2005, 69, 4773-4785. [CrossRef]

56. Mangalo, M.; Meckenstock, R.U.; Stichler, W.; Einseidl, F. Stable isotope fractionation during bacterial sulfate reduction is controlled by reoxidation of intermediates. Geochim. Cosmochim. Acta 2007, 71, 4161-4171. [CrossRef]

57. Rosen, M.R. Sedimentological and geochemical constraints on the evolution of Bristol Dry Lake basin, California, U.S.A. Palaeogeog. Palaeoclim. Palaeoecol. 1991, 84, 229-257. [CrossRef]

58. Longinelli, A.; Craig, H. Oxygen-18 variations in sulfate ions in sea-water and saline lakes. Science 1967, 156, 1431-1438. [CrossRef]

59. Yang, W.; Krouse, H.R.; Spencer, R.J.; Lowenstein, T.K.; Hutcheon, I.E.; Ku, T.-L.; Li, J.; Roberts, S.M.; Brown, C.B. A 200,000-year record of change in oxygen isotope composition of sulfate in a saline sediment core, Death Valley, California. Quat. Res. 1999, 51, 148-157. [CrossRef]

60. Synkiewicz, A.; Ewing, R.C.; Moore, C.H.; Glamoclija, M.; Bustos, D.; Pratt, L.M. Origin of terrestrial gypsum dunes-Implications for Martian gypsum-rich dunes of Olympia Undae. Geomorphology 2010, 121, 69-83. [CrossRef] 
61. Bates, T.S.; Lamb, B.K.; Guenther, A.; Dignon, J.; Stoiber, R.E. Sulfur emissions to the atmosphere from natural sources. J. Atmos. Chem. 1992, 14, 315-337. [CrossRef]

62. Spiro, P.A.; Jacob, D.J.; Logan, J.A. Global inventory of sulfur emissions with $10 \times 10$ resolution. J. Geophys. Res. 1992, 97, 6023-6036. [CrossRef]

63. Gu, A. Stable Isotope Geochemistry of Sulfate in Groundwater of Southern Arizona: Implications for Groundwater Flow, Sulfate Sources, and Environmental Significance. Ph.D. Thesis, University of Arizona, Tucson, AZ, USA, 2005.

64. Kayaci, H. Recharge Estimation by the Chloride Mass Balance Method in the Tucson Basin. Master's Thesis, Man. University of Arizona, Tucson, AZ, USA, 1997.

65. Zamora, H.A.; Eastoe, C.J.; McIntosh, J.C.; Flessa, K.W. Groundwater Origin and Dynamics on the Eastern Flank of the Colorado River delta, Mexico. Hydrology 2021, 8, 80. [CrossRef]

66. Bao, H.; Reheis, M.C. Multiple oxygen and sulfur isotopic analyses on watersoluble sulfate in bulk atmospheric deposition from the southwestern United States. J. Geophys. Res. 2003, 108, 4430. [CrossRef]

67. Pasilis, S. Isotopic and Chemical Characterization of Groundwater in the Northern Tucson Basin. Master's Thesis, University of Arizona, Tucson, AZ, USA, 1999.

68. Barger, E.E. Migration of Recharge Water Downgradient from the Santa Catalina Mountains into the Tucson Basin Aquifer. Master's Thesis, Man. University of Arizona, Tucson, AZ, USA, 1996.

69. Wanty, R.B.; Shanks, W.C., III; Lamothe, M.A.; Lichte, F.; Briggs, P.H.; Berger, B.R. Results of Chemical and Stable Isotopic Analyses of Water Samples Collected in the Patagonia Mountains, Southern Arizona; US Geological Survey Open-File Report 01-363; United States Government Printing Office: Washington, DC, USA, 2001.

70. Schrag-Toso, S.C. Isotopes, Geochemistry, Citizen Science and Local Partnerships as Tools to Build upon a Fractured Understanding of the Hydrology of the Northern Patagonia Mountains. Master's Thesis, University of Arizona, Tucson, AZ, USA, 2020.

71. Ohmoto, H.; Rye, R. 0. Isotopes of sulfur and carbon. In The Geochemistry of Hydrothermal Ore Deposits; Barnes, H.L., Ed.; John Wiley and Sons: New York, NY, USA, 1979; pp. 509-567.

72. Enders, M.S. The Evolution of Super Gene Enrichment in the Morenci Porphyry Copper Deposit, Greenlee County, Arizona. Ph.D. Thesis, University of Arizona, Tucson, AZ, USA, 2000.

73. Lang, J.R.; Guan, Y.; Eastoe, C.J. Stable isotope studies of sulfates and sulfides in the Mineral Park Porphyry Cu-Mo System, Arizona. Econ. Geol. 1989, 84, 650-662. [CrossRef]

74. Gustafson, L.B.; Hunt, J.P. The porphyry copper deposit at El Salvador, Chile. Econ. Geol. 1975, 70, 857-912. [CrossRef]

75. Titley, S. Advances in Geology of the Porphyry Copper Deposits, Southwestern North America; University of Arizona Press: Tucson, AZ, USA, 1982.

76. Cook, S.S., III. The Geological History of Supergene Enrichment in the Porphyry Copper Deposits of Southwestern North America. Ph.D. Thesis, University of Arizona, Tucson, AZ, USA, 1994.

77. Erjavec, J.L. The Sulfur Distribution in the Sedimentary Rocks of Southeast Arizona. Master's Thesis, University of Arizona, Tucson, AZ, USA, 1981.

78. Dickinson, W.R.; Fiorillo, A.F.; Hall, D.L.; Monreal, R.; Potochnik, A.R.; Swift, P.N. Cretaceous strata of southern Arizona. In Geologic Evolution of Arizona. Arizona Geol. Soc. Digest 1987, 17, 447-461.

79. Schafroth, D.W. Structure and stratigraphy of the Cretaceous rocks in south of Empire Mountains, Pima and Santa Cruz Counties, Arizona. Ph.D. Thesis, University of Arizona, Tucson, AZ, USA, 1965.

80. Taliaferro, N.L. An occurrence of Upper Cretaceous sediments in northern Sonora, Mexico. J. Geol. 1933, 41, 12-37. [CrossRef]

81. Valencia, V.A.; Eastoe, C.J.; Ruiz, J.; Ochoa-Landin, L.; Gehrels, G.; Gonzalez-Leon, C.; Barra, F.; Espinoza, E. Hydrothermal evolution of the porphyry copper deposit at La Caridad, Sonora, Mexico, and the relationship with a neighboring high-sulfidation epithermal deposit. Econ. Geol. 2008, 103, 473-491. [CrossRef]

82. Graybeal, F.T. The Geology and Gypsum Deposits of the Whetstone Mountains, Cochise County, Arizona. Master's Thesis, University of Arizona, Tucson, AZ, USA, 1962.

83. Eastoe, C.J. Report on an Isotope Study of Groundwater from the Mogollon Highlands Area and Adjacent Mogollon Rim, Gila County, Arizona. 2007. Available online: https://www.geo.arizona.edu/sites/www.geo.arizona.edu/files/Eastoe_2007 _MRWRMS.pdf (accessed on 27 August 2021).

84. Lewis, J.L. Geochemical Evolution of Water in the Central Tucson Basin, Arizona; Master's Prepub. Manuscript; University of Arizona: Tucson, AZ, USA, 1996.

85. Eastoe, C.J.; Gustin, M.S.; Orr, R.; Hurlbut, D. Sulfur isotope geochemistry of lower Proterozoic massive sulfide deposits: New data from Arizona, and implications for the chemistry of contemporaneous seawater. Precambrian Res. 1990, 46, 353-364. [CrossRef]

86. Coleman, M.; Moore, M.P. Direct reduction of sulfates to sulfur dioxide for isotopic analysis. Anal. Chem. 1978, 50, 1594-1595. [CrossRef]

87. Robinson, B.A. Sulphur isotope standards. In Reference and Intercomparison Materials for Stable Isotopes of Light Elements; International Atomic Energy Agency Tecdoc 825: Vienna, Austria, 1995; pp. 39-46.

88. Gu, A.; Gray, F.; Eastoe, C.J.; Norman, L.; Duarte, O.; Long, A. Tracing ground water input to base flow using sulfate (S., O) isotopes. Ground Water 2008, 46, 502-509. [CrossRef] [PubMed]

89. Guilbert, J.M.; Park, C.F. The Geology of Ore Deposits; W.H. Freeman: New York, NY, USA, 1986. 
90. National Parks Service. Overview of the Geology of White Sands National Monument. 2020. Available online: https: //www.nps.gov/whsa/learn/nature/upload/Overview_of_the_Geology_of_White_Sands_National_Monument_03_07_16_1-6MB_PDF.pdf\#: \{\}:text=Overview\%20of\%20the $\% 20$ Geology $\% 20$ of $\% 20$ White $\% 20$ Sands $\% 20$ National,across $\% 20$ the $\% 20$ base $\%$ 20of\%20the\%20San\%20Andres\%20Mountains (accessed on 1 November 2021).

91. Rosales Dominguez, M.d.C. Micropaleontology and Paleogeography of the Upper Mural Limestone of Southeastern Arizona and Northern Sonora. Master's Thesis, University of Arizona, Tucson, AZ, USA, 1989.

92. Mark, R.A. Structural and Sedimentary Geology of the Area North of Hot Springs Canyon, Southern Galiuro Mountains, Cochise County, Arizona. Master's Thesis, University of Arizona, Tucson, AZ, USA, 1985.

93. Warzeski, E.R. Facies Patterns and Diagenesis of a Lower Cretaceous Carbonate Shelf: Northeastern Sonora and Southeastern Arizona (Mexico). Ph.D. Thesis, State University of New York, Binghamton, NY, USA, 1983.

94. Rauzi, S.L. Permian salt in the Holbrook Basin, Arizona; Arizona Geological Survey Open-File Report OFR-00-03; Arizona Geological Survey: Tucson, AZ, USA, 2000. 